\title{
WE MATTER TOO: BLACK WOMEN AND THEIR EXPERIENCES DUE TO APPLIED STREAMING IN THE ONTARIO SECONDARY SCHOOL SYSTEM
}

\author{
by
}

Marlesa Olivia Ward, BSW, Ryerson University, 2019

\author{
An MRP \\ Presented to Ryerson University \\ In partial fulfillment of the \\ requirements for the degree of \\ Master of Social Work \\ In the Program of \\ Social Work
}

Toronto, Ontario, Canada, 2020

(C) Marlesa Olivia Ward 2020 


\section{AUTHOR'S DECLARATION FOR ELECTRONIC SUBMISSION OF A MRP}

I hereby declare that I am the sole author of this MRP. This is a true copy of the MRP, including any required final revisions.

I authorize Ryerson University to lend this MRP to other institutions or individuals for the purpose of scholarly research

I further authorize Ryerson University to reproduce this MRP by photocopying or by other means, in total or in part, at the request of other institutions or individuals for the purpose of scholarly research.

I understand that my MRP may be made electronically available to the public. 


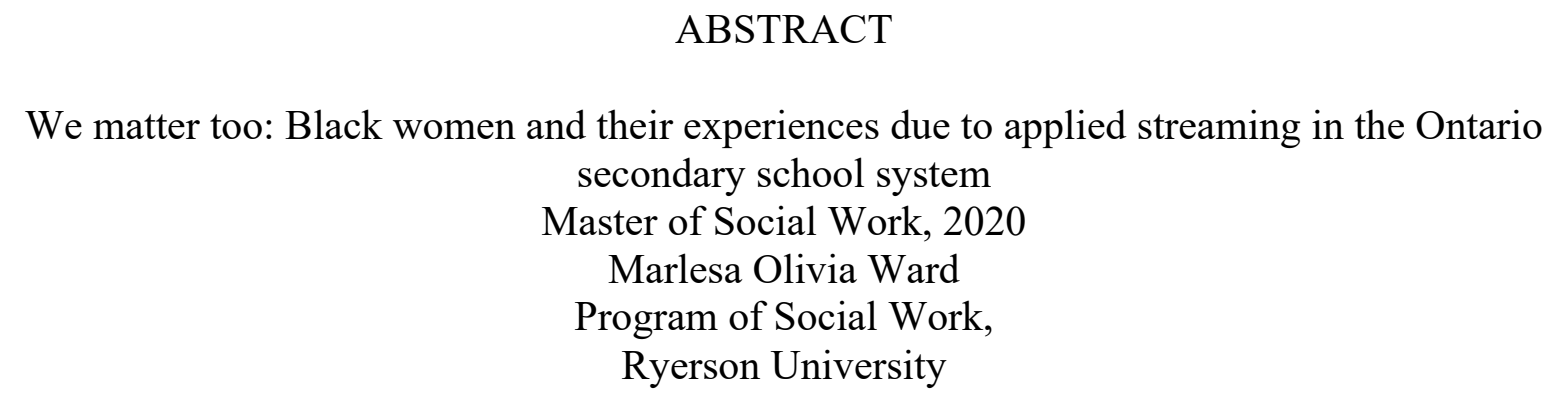

This narrative and arts-based qualitative research study examines life experiences of Black women due to applied streaming in the Ontario secondary school system through an AntiBlack Racism (ABR) and a Black Canadian Feminism framework. Two Black women adults in Toronto or the greater Toronto area who went to an Ontario secondary school in the past and were streamed into applied courses were interviewed. Also, an expert in the educational field was interviewed to bring in insider knowledge about social workers role with respect to streaming. ABR and Black Canadian Feminism helped to gain an appropriate and detailed understanding of what Black females experiences look like. Black Canadian Feminism allowed for Black women's stories to finally be heard and valued. The data was analyzed via line by line analysis which captures every topic and discourse in order to display a proper portrayal of Black women's narratives. 


\section{ACKNOWLEDGEMENTS}

I would like to take this opportunity to thank many individuals who have supported me throughout my educational journey. Firstly, I would like to thank God for giving me the strength, motivation, determination, discipline, and intelligence that was needed to complete this journey. I would like to thank my amazing mom Marlene Nesbeth-Ward, sister Brianna Ward, grandma Fern Stewart, my partner Romario Bonnick, and also my classmates for continuously encouraging me and assisting me throughout this process. Thank you to all of the Ryerson University professors who took the time to help me. To my supervisor Dr. Ken Moffatt thank you very much for your suggestions, feedback, and guidance throughout this whole Major Research Paper process. Last but not least thank you to the wonderful participants/co-creators who took the time out especially throughout the COVID-19 pandemic to take part in this research because without your participation this Major Research Paper would not be possible. 


\section{DEDICATION}

I dedicate this Major Research Paper to my mom Marlene Nesbeth-Ward, sister Brianna Ward, grandma Fern Stewart and partner Romario Bonnick because this would not be accomplished without their support. I also, dedicate this Major Research Paper to all the participants/co-creators of this study, to all the Black women, and Black People that live in Ontario specifically Toronto and the greater Toronto area. 


\section{TABLE OF CONTENTS}

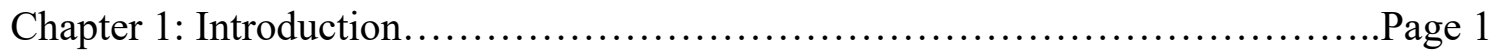

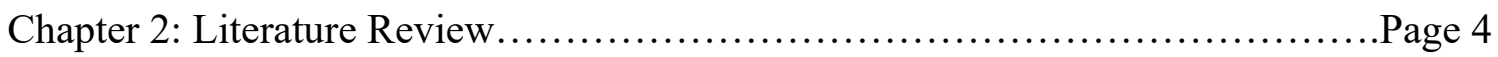

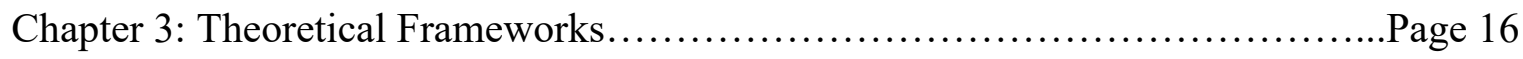

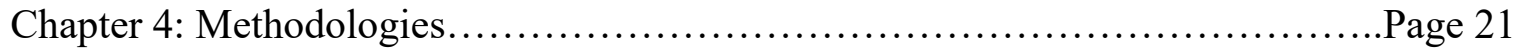

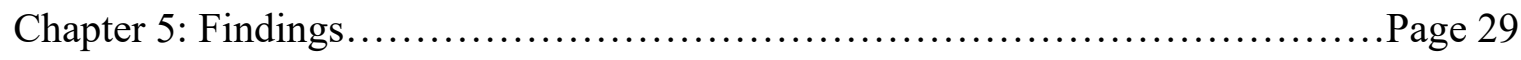

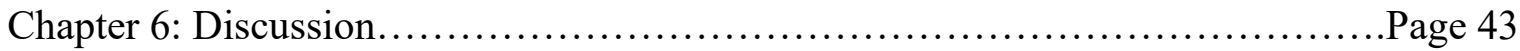

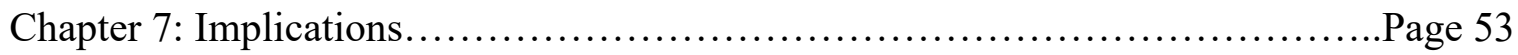

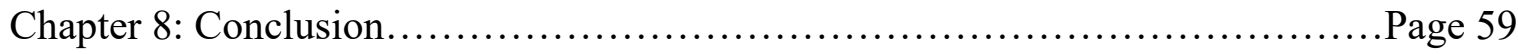

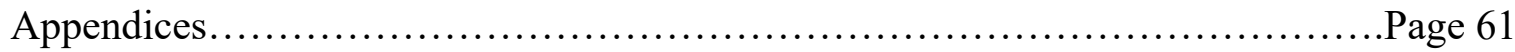

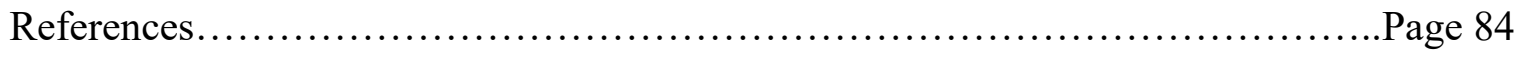




\section{LIST OF APPENDICES}

$\begin{array}{ll}\text { Appendix A - Recruitment Flyer } & \text { Page } 61\end{array}$

Appendix B - Email Recruitment for Educational Expert Page 62

Appendix C - Consent Form for Black Women Page 64

Appendix D - Consent Form for Educational Expert $\quad$ Page 70

Appendix E - Interview Guide for Black Women Page 76

$\begin{array}{ll}\text { Appendix F - Interview Guide for Educational Expert } & \text { Page } 77\end{array}$

$\begin{array}{ll}\text { Appendix G - List of Services } & \text { Page } 78\end{array}$

Appendix H - Online Image for Educational Expert Page 80

Appendix I - Abstract Drawing for one Black woman $\quad$ Page 81

Appendix J - Abstract Drawing for one Black woman $\quad$ Page 83 


\section{CHAPTER 1. INTRODUCTION}

This research study is about applied streaming in the Ontario secondary school system. Streaming is the placement of students based on their "ability" or "inability", if students are deemed unable, they are placed in applied courses (college preparation) and if they are deemed able, they are placed in academic courses (university preparation) (James \& Turner, 2017). My specific focus is around two research questions. 1) What are Black women's experiences due to applied streaming in the Ontario secondary school system? 2) What are social workers role with

respect to streaming in the Ontario secondary school system. For Black students, this process of streaming occurs in ways which cause them to be streamed in applied courses which are usually below their ability (James \& Turner, 2017). This practice in the Ontario secondary school system showcases the low expectations and the anti-Black racism (ABR) from teachers, guidance counsellors and other school personnel (James \& Turner, 2017).

This practice of streaming Black students in Ontario under their ability has resulted in an overrepresentation of Black students in applied courses with $39 \%$ being placed into applied courses compared to $18 \%$ of other racialized students and $16 \%$ of White students (James \& Turner, 2017). This supports the prejudicial assumption that Black students are not able to be successful and that they do not belong in academic streams (James \& Turner, 2017). Furthermore, this social issue is significant to social work, since Black students do not feel comfortable speaking to educators or guidance counsellors because the students are encouraged from them to be in applied streams. Students also experience racism from educators and guidance counsellors (James \& Turner, 2017). It is important to explore the role of social workers with respect to streaming in the Ontario secondary school system. Research can help 
reveal the role of social workers as well as help to define a helpful role in giving guidance and support to Black students with respect to the experience of streaming.

Streaming continues to transpire and affect Black students in Canada. Scholars have brought forward how this social issue affects Black people's lives including institutional AntiBlack Racism, internalized Anti-Black Racism, educational and employment barriers for Black students, as well as the school to prison pipeline. Studies have researched stories from Black males regarding how applied streams have affected their lives, but there has been little to no studies on Black female's experiences. With a social work lens to this topic, space will be provided for Black females to tell their stories from which to fully understand how this issue affects all Black peoples and the role of social workers will be looked into.

My motivation and passion for this research topic stems from my personal experience in applied courses within the Ontario secondary school system. I am a Black, Afro-Caribbean, Canadian, heterosexual, woman who has attended secondary school in Ontario specifically in the Region of Peel. When I was in secondary school my guidance counsellor referred me to applied courses because in her words "I would not be able to manage academic courses because they would be too hard for me." I listened because at the time I thought that guidance counsellors and teachers knew best and would guide me in the right direction. I was embarrassed to be in applied courses because I honestly did not think it captured my full potential. Being encouraged to go into applied streams even though I wanted to be in an academic stream made me believe that I was stupid and that I had no chance of being successful in my life. I had no one to talk to at school because my guidance counsellor and teachers believed that this was the path for me. At home, my mom was my only cheerleader which felt like nothing to me because that was a mother's role in my eyes. It did not help that my dad and my peers at school believed that 
applied courses were the right choice for me, which to my mind meant that my dad and my peers believed I was stupid as well. With that being said, I thought that community college was the best way to go. But I was not sure I could get in. I did get into college, but this streaming practice ruined my confidence and I never thought in a million years that I would be able to get into university to do my Bachelor's in Social Work. Then I never thought in a trillion years that I would be doing my Master's in Social Work. Even though I got into university the streaming practice made my educational path more difficult to navigate from secondary school into university. Also, I suffered and still do with low self-esteem because of the Anti-Black racism that I have experienced both personally and institutionally.

I hope to contribute to further activism and awareness of this anti-Black racist practice in general, and in particular to Black women's experiences like myself through the sharing of participants/co-creator's stories and research findings. The next chapters will speak about the literature reviewed: summary of themes present concerning to this topic, limitations and gaps, how my approach will address these gaps. Also, my theoretical frameworks that inform this study and my methodology which will look at my design, approaches of inquiry, participants, recruitment strategy, data collection, and data analysis. My findings chapter will touch on the sources of information, and the different topics from the findings. The discussion chapter will focus on the interpretation of the findings through my theoretical frameworks and the context of the literature review, and how my results answer my research questions. The implication chapter will look at ethics, strengths and limitations, and implications to social work practice, policy, education, and research. Lastly, my conclusion will summarize everything. 


\section{CHAPTER 2. LITERATURE REVIEW}

The themes included in the literature review are Anti-Black Racism (ABR) and role of teachers, Whiteness and White supremacy, school to prison pipeline, educational and employment barriers for Black students, as well as Black women and applied streaming. After I speak on the themes, I will mention limitations and gaps throughout the literature. The literature reviewed mainly incorporated qualitative studies from American and Canadian sources. Authors such as Carr \& Klassen, 1997; Codjoe, 2006; Dei, 1997; Duhaney, 2010; Galabuzi, 2014; James \& Turner, 2017; Katshunga et al., 2020; Neeganagwedgin, 2014; Oba, 2018; Owusu-Bempah, 2014; Prah, 2016; Salole \& Abdulle, 2015; Schroeter \& James, 2015; Wood, 2011 are Canadian scholars. Therefore, anything mentioned in the literature review with these authors names specifically speak about Ontario or the Toronto and greater Toronto area in Ontario. Within the literature disciplines that were present include: social work, sociology, education, and youth studies.

\section{ABR \& Role of Teachers}

The social construction of race has a pervasive influence on how Black people experience schooling (Briggs, 2018; Carr \& Klassen, 1997; Dei, 1997; Chambers, 2009; Duhaney, 2010; Hope, Skoog, \& Jagers, 2015; James \& Turner, 2017; Neeganagwedgin, 2014; Prah, 2016; Schroeter \& James, 2015). Individuals who identify as Black are viewed through stereotypes or labels, such as, being "unintelligent" and "unable" to take academic courses (Briggs, 2018; Carr \& Klassen, 1997; Dei, 1997; Chambers, 2009; Duhaney, 2010; Hope, Skoog, \& Jagers, 2015; James \& Turner, 2017; Neeganagwedgin, 2014; Prah, 2016; Schroeter \& James, 2015). These labels have contributed to how some scholars have looked at high numbers of Black people who are streamed as an "achievement gap". One study spoke about how "achievement gap" is a label 
that further perpetuates and reinforces ABR because it puts the responsibility on Black people for their ability to achieve (Chambers, 2009). This is why it is important to look at this issue as a "receivement" gap which puts the onus on how others view or receive Black people (Chambers, 2009).

These stereotypes of being "unable" and "unintelligent" have been traced back to history (slavery days) when slaves were prevented from their White owners to learn how to read and write (Duhaney, 2010; James \& Turner, 2017). During these times Black people were forced to go to segregated schools which were looked at as nothing compared to the elite schools and education Whites were receiving (Duhaney, 2010; James \& Turner, 2017). Black schools were looked at as nothing due to the Black bodies that attended the schools because Blackness is viewed as "less than" (Dei, 1997). Also, nothing meant that the type of education being taught in Black schools were not as in depth as White schools (Duhaney, 2010). The misrepresentation of Black people continues into contemporary times as segregation is perpetuated through streaming programs (Kelly, 2009). This allows for the overrepresentation of Black people to be streamed into applied level courses, pressured to choose them, and this leaves their dreams and abilities untapped (Briggs, 2018).

According to Codjoe (2006) these racist labels of being "unintelligent", "unable", "lazy", "mentally incompetent" to take or manage academic courses are reinforced through the role of teachers. The literature showcases that guidance counsellors, and teachers frequently discourage Black people from taking academic courses and instead encourage them to take applied courses (Briggs, 2018; Carr \& Klassen, 1997; Chambers, 2009; Dei, 1997; Hope et al., 2015; James \& Turner, 2017; Neeganagwedgin, 2014; Schroeter \& James, 2015). James \& Turner (2017) argue that the operation of the streaming process in relation to Black people is that they are overly put 
into applied courses which are below their ability. This reflects the low expectations that guidance counsellors and other educators have of Black people (Briggs, 2018; Carr \& Klassen, 1997; Chambers, 2009; Dei, 1997; Duhaney, 2010; Hope et al., 2015; James \& Turner, 2017; Neeganagwedgin, 2014; Prah, 2016; Schroeter \& James, 2015).

Many teachers and guidance counsellors in Ontario identify as White (James \& Turner, 2017). Teachers and guidance counsellors are the ones with the power to stream Black people in the Ontario secondary school system (Briggs, 2018; Carr \& Klassen, 1997; Chambers, 2009; Duhaney, 2010; Hope et al., 2015; James \& Turner, 2017; Neeganagwedgin, 2014). Also, teachers, guidance counsellors, and other educators do not just think about these anti-Black racist stereotypes they also say them vocally towards Black people (Briggs, 2018; Carr \& Klassen, 1997; Chambers, 2009; Duhaney, 2010; Hope et al., 2015; James \& Turner, 2017;

Neeganagwedgin, 2014). Teachers and guidance counsellors say statements such as you are all savages, you are not smart enough to get into university, I think college is the best place for you (James \& Turner, 2017). These statements make Black people experience internalized ABR which leads some Black people to believe that they are inferior and believe that these statements are correct and therefore they should be satisfied with applied courses (Tyson et al., 2005). In addition, because of internalized ABR, Black students choose applied streams for themselves because they fear they will not succeed in academic streams (Tyson et al., 2005). Black people's motivation to go into applied streams is tied to those dominant stories of Black people and their level of intelligence (Tyson et al., 2005). Black people will tell themselves that they cannot manage the course load or the level of work in academic streams (Tyson et al., 2005). Black people believe and accept that school personnel such as teachers and guidance counsellors are correct about what they can and cannot do and start to act out those stereotypes (Tyson et al., 
2005). Internalized ABR helps to shape Black people's identities by allowing them to feel less intelligent and lower their self-esteem (Tyson et al., 2005).

Many Black people in Ontario have intentions to go to university but do not understand the implications of being satisfied in applied courses, because most times guidance counsellors do not explain this to them (James \& Turner, 2017). This is one of the duties that guidance counsellors have which is to explain the implications of applied courses to all students including Black students (James \& Turner, 2017). White people were supported to do well in academic and applied courses even if they were experiencing difficulties (James \& Turner, 2017). Meanwhile Black people were not given that same support and encouragement in relation to their process with streaming whether applied or academic (James \& Turner, 2017).

Many Black people in Ontario state that low outcomes for them such as being put automatically into applied courses or choosing applied courses is partly connected to the curriculum and the fact that it is not responsive to their interests or needs (James \& Turner, 2017). Black people struggle to connect or to feel determined and motivated because the Ontario curriculum is mostly centered around a Western European lens (James \& Turner, 2107). One Black person said that "Black history is White-washed in the Ontario curriculum" (James \& Turner, 2017, pg. 61). Ontario secondary schools are sending a specific message about cultural diversity, equity, and inclusiveness especially to Black people (James \& Turner, 2017). Some teachers try to include Black cultural, social and historical concepts but fail to be successful due to their lack of knowledge (James \& Turner, 2017). Black people state that even if teachers and guidance counsellors are not openly malicious regarding ABR they still use ABR based microaggressions which cause serious emotional and mental harm (James \& Turner, 2017).

\section{Whiteness \& White Supremacy}


Whiteness is a social construction based on White skin being a privilege. This privilege allows for White supremacy because White skin is constructed as the highest ranking in Canadian society (Dei, 1997). It is the norm for most people, so it is embedded within the Ontario secondary school system (Dei, 1997). The expression of Whiteness devalues the image of Blackness because it gives negative meaning and attention to Blackness such as those stereotypes and labels mentioned above. It allows for White people to deny their complicity in racism specifically in this case of ABR (Dei, 1997).

Teachers, educators, and guidance counsellors in Ontario are mostly White (James \& Turner, 2017). Their skin colour has benefited them in terms of hiring, promotion, and influence (Carr \& Klassen, 1997). This benefit within the Ontario secondary school system has resulted in them either automatically streaming Black people into applied tracks or pressuring Black students to choose applied tracks (Carr \& Klassen, 1997). When asked about their role in disproportionately doing this to Black people teachers and guidance counsellors state that it has nothing to do with race it is difficult to meet the needs of all students (Schroeter \& James, 2015). Teachers and guidance counsellors say it is not significant for any kind of anti-racist education to be present because they are not racist, and they do not see the overrepresentation of streaming Black people as an issue (Carr \& Klassen, 1997; Schroeter \& James, 2015).

With White teachers benefiting from their Whiteness in taking up majority of the teacher or guidance counsellor roles, the image of Blackness becomes devalued in this normalized expression of Whiteness because Black teachers do not get the same opportunities (Oba, 2018). Many Black teachers play a positive role in preventing ABR and supporting Black students (Oba, 2018). But even though that is the case Black participants in Ontario who took part in the Oba (2018) study mentioned that they only had one or two Black teachers while some other 
participants noted that they never had a Black teacher throughout their entire secondary school education.

Furthermore, Whiteness and White supremacy is shown throughout the studies of streaming in relation to how many White people are favored to be enrolled in academic streams compared to Black people and how much Black people are enrolled in applied compared to White people (James \& Turner, 2017). James \& Turner (2017) state that 53\% of Black people in Ontario were enrolled into academic courses compared to $81 \%$ of White students. Black people in Ontario were about twice as likely to be placed into applied courses at 39\% compared to $16 \%$ of White people (James \& Turner, 2017).

Black people specifically Black males within the Briggs (2018) study mentioned that they feel forced on whether to choose to embrace their own cultural identity or assimilate to White norms. The reason they feel like they have to choose is because White norms are viewed as acceptable and link to educational and employment opportunities because society is embedded in White domination (Briggs, 2018). Also, the need to choose comes from the fact that the Black male body is looked at as inferior and unacceptable from the White gaze but if they assimilate to White norms they will be accepted more (Briggs, 2018).

\section{School to prison pipeline}

Applied streaming is an accomplice to powerful disciplinary practices such as zero tolerance policies that push Black people out of school (Dei et al. 1997; Galabuzi 2014; Meiners, 2007, Owusu-Bempah, 2014). The school to prison pipeline, for example, is a combination of policies and practices within the education and criminal justice system that work together to push Black males out of school and into corrections (Allen \& White-Smith, 2014; Grace \& Nelson, 
2018, Owusu-Bempah, 2014). Morris (2007) states that the school to prison pipeline does not only push out Black males into corrections but also Black females. Yang et al. (2019) argue the school to prison pipeline occurs as a result of a failed education system that does not meet the needs of certain students (Yang et al., 2019). This idea of a school to prison pipeline is reserved for schools which connect race to fear (Owusu-Bempah, 2014, Salole \& Zakaria, 2015). There is a poor relationship between teachers and guidance counselors with Black people because they encourage them to be in applied streams which makes it difficult for Black people to want to engage in school (Grace \& Nelson, 2018).

With not wanting to engage in school due to being placed in streams often times below their ability, Black people in Ontario display behaviours in the form of talking back to teachers and other educators because of the way they are being treated unfairly (James \& Turner, 2017; Morris, 2007). Black people in Ontario also "talk back" because they want to feel humanized rather than dehumanized (James \& Turner, 2017; Morris, 2007). These are forms of resistance to ABR and discrimination that they experience in school (James \& Turner, 2017). But why they were acting out did not matter because at the end of the day they were treated more severely for minor offenses such as resistance compared to other racial groups and White people (Grace \& Nelson, 2018; James \& Turner, 2017, Owusu-Bempah, 2014). Black people in the Grace \& Nelson (2018) and James \& Turner (2017) studies state that this treatment has been happening from preschool so that Black students have been targeted throughout their whole school career.

The presence of police officers in Ontario schools further strengthened the process of criminalization and the school to prison pipeline (Owusu-Bempah, 2014). Ontario schools are more prone to put officers in schools that have a large Black population due to stereotypes about Black people (Owusu-Bempah, 2014). Teachers and other school personnel usually act on 
stereotypes instead of actual evidence which further marginalizes and criminalizes Black people (Owusu-Bempah, 2014).

The James \& Turner (2017) study looked into the collaboration of the Ontario secondary school system, police, and child welfare system and how they collaborate to push Black people into the Ontario criminal justice system. Teachers and other school personnel contact child welfare in order to force parents to move their Black child to another school or program. Also, James \& Turner (2017) declare that teachers call child welfare when a Black child "acts out". The reason why is because they want to make it seem like the behaviour is due to issues going on in the home instead of looking at the real cause which is racist bullying at school from both peers and teachers (James \& Turner, 2017).

\section{Educational and Employment Barriers}

Streaming also plays a major role in transitioning to post-secondary and the completion of post-secondary in Black people's lives (Kao \& Thompson, 2003). Several Black people have high goals in going to post-secondary, but this does not necessarily translate into the physical transition into college or university (Kao \& Thompson, 2003). Kao \& Thompson (2003) state that Black people take longer to transition into post-secondary, and when it comes to completing post-secondary many Black people drop out in comparison to White people. Black people take longer to transition and usually drop out due to the differences in academic preparation during their time in Ontario secondary schools (James \& Tuner, 2017; Kao \& Thompson, 2003). By Black people being streamed into applied streams from early on in their education, it slows them down, and makes a negative impact on their future (Kao \& Thompson, 2003). For instance, with the overrepresentation of Black people being streamed into applied courses this means that there will be more Black people going into community college instead of university based on the 
applied courses they were streamed into from secondary school (Kao \& Thompson, 2003). Therefore, there is a racial hierarchy that is present throughout the whole academic experience (Kao \& Thompson, 2003).

In the Briggs (2018) study Black males mentioned that in order to enhance professional development for Black students to be prepared for employment culturally relevant practices are needed in secondary schools and all levels of education. Even if Black males and other Black people have employment options to choose from, they still feel lost and lack clear plans for the

future (Briggs, 2018). This showcases the significance of teachers and guidance counselors with helping Black males and other Black people in regard to their future (Briggs, 2018). Many secondary schools do not have programs that will support isolated students such as Black students who are not receiving proper supports to develop a sense of agency and high self-esteem (Briggs, 2018). Black people are left on their own to navigate the educational system and to transition into employment which increases their chances of dropping out or being limited to the precarious employment market (Briggs, 2018).

\section{Black Women \& Applied Streaming}

There is a scarcity in relation to research about Black women's experiences within all levels of the Ontario educational system including the Ontario secondary school system (Katshunga et al., 2020). There are very few sources or research that track Black female's experiences and educational outcomes especially in connection with applied streaming (Katshunga et al., 2020; Neeganagwedgin, 2014). Not much is known about Black female's stories, especially the difficulties they face with applied streaming based on their gender in Ontario (Wood, 2011). In the limited research pertaining to Black females that do exist tend to only focus on their educational achievements compared to White females (Neeganagwedgin, 
2014). Also, there is focus on Black females outperforming Black males in elementary and secondary school and how they are more likely to graduate secondary school even though they face their own barriers with applied streaming (Katshunga et al., 2020). In relation to their gender Black females have to face sexual stereotypes and perceptions pertaining to their low educational goals and achievements in school (Crenshaw et al., 2015; Katshunga et al., 2020; Morris, 2007. In addition, an American study by Orenstein (1994) states that Black American females have an increased sense of pessimism regarding schoolwork and teachers. But this is not recognized because Black males tend to capture a significant amount of teacher's attention whether negative or positive which makes Black females invisible (Crenshaw et al., 2015; Orenstein, 1994).

\section{Limitation and Gaps}

This research addresses three significant gaps in the literature. Firstly, the lack of research about the experience of Black women and streaming. Secondly, that the lack of literature about the role of social workers with respect to streaming. This research is the first piece of research to use an Anti-Black Racism lens to the topic.

Much of the literature only focused on Black male's experiences due to being streamed below their ability in secondary school. Other literature spoke on Black people as a whole but prioritized the effect on Black males' experiences at certain points. Out of all the literature only eight of the articles focused on Black females with two of them focused on zero tolerance policies in connection to small parts about applied streams, and six of those eight articles speaking specifically to applied streaming. Two out of the six are autoethnographies that focus

on the researchers who identify as Black females and their experiences with streaming (Duhaney, 2010; Prah, 2016). The third, fourth, and fifth piece of literature focused solely on Black females 
instead of the researcher. The concerns with these pieces of literature is that there were no Black women as participants voicing their experiences from their own perspective (Katshunga et al., 2020). Instead the authors were stating information about Black women and or their experiences within the education system and applied streams (Katshunga et al., 2020; Orenstein, 1994; Wood, 2011). The sixth piece of literature focused on Black females instead of the researcher as well and was the only one in which Black females were participants voicing their narratives about their educational experiences such as applied streaming (Neeganagwedgin, 2014). Therefore, Black females voices specifically in regard to their experiences coming from their point of view due to applied streaming is limited and silenced (Briggs, 2018; Carr \& Klassen, 1997; Chambers, 2009; Dei, 1997; Duhaney, 2010; Hope et al., 2015; James \& Turner, 2017; Neeganagwedgin, 2014; Prah, 2016; Schroeter \& James, 2015). With that being said I will be addressing a gap in the literature by focusing on Black women's experiences due to applied streaming in the Ontario secondary school system through a Black Feminist framework. Many of the studies spoke about the role of teachers (Briggs, 2018; Carr \& Klassen, 1997; Chambers, 2009; Dei, 1997; Hope et al., 2015; James \& Turner, 2017; Neeganagwedgin, 2014; Schroeter \& James, 2015). But there was no mention of social workers who are also present within schools (Briggs, 2018; Carr \& Klassen, 1997; Chambers, 2009; Dei, 1997; Duhaney, 2010; Hope et al., 2015; James \& Turner, 2017; Neeganagwedgin, 2014; Prah, 2016; Schroeter \& James, 2015). There is a gap in the research about how social workers could be of support when Black people feel inferior because they are being persistently streamed below their ability. They are being streamed below their ability by teachers and guidance counsellors so they will not feel comfortable going to them for any kind of support. It is important for research to include social workers to see what their role is in all of this or if they even have a role, as they 
can be of help with this issue because of their education and training on anti-oppressive practices. Therefore, I will address this gap by focusing on social workers role with streaming in the Ontario secondary school system.

Most of the research studies are in disciplines such as sociology, youth studies, and education rather than social work. There is one study (Duhaney, 2010) that was in a social work discipline and was published in a social work journal. Duhaney (2010) did not say anything about social workers but she is a social worker herself who did a critical autoethnography about her own experience with applied streaming in the past. This impacts what is known about the topic because it is only looked at from an education lens which makes it an "education issue" in which only educators can take part in. But if social work as a discipline starts becoming involved and once research starts to incorporate social workers role then this will enrich and add to the research out there about applied streaming and Black people.

Although all of the literature speaks on ABR they only speak about it as a form of racism. Additionally, no research has looked at this social issue through an ABR framework but instead majority of the literature has focused on this social issue through a critical race theory (CRT) framework that touches on ABR as a category under CRT. Therefore, to address this gap my study will bring awareness to this social issue through an ABR framework as streaming is an anti-Black racist practice that targets Black people. Through these limitations and gaps in the research about streaming this study attempts to answer the following research questions: What are Black women's experiences due to applied streaming in the Ontario secondary school system? What are social workers role with respect to streaming in the Ontario secondary school system? 


\section{Chapter 3: Theoretical Frameworks}

The theoretical frameworks that inform this major research paper are ABR and Black Canadian Feminism. These two theoretical frameworks guide the researcher in fully understanding and highlighting the experiences of Black women due to applied streaming in the Ontario secondary school system. Pon et al. (2011) states that ABR is a specific form of racism that Black people experience in Canada that it is deeply rooted in colonialism and slavery. ABR highlights and brings awareness to certain practices and laws that lead to issues with employment, housing, and segregation in education, for example the disproportionate amount of applied streaming experienced by Black individuals in Canada compared to White individuals (James et al., 2010).

$\mathrm{ABR}$ is critical in relation to the research questions, methodologies, methods, and this research study as a whole because Black women's experiences are vital in addressing racism, colonialism, and White supremacy in Canadian society (Clarke et al., 2015). Furthermore, ABR is necessary to inform this research study on all levels because it critiques, resists and provides a basis to eliminate ABR (Clarke et al., 2015; Dei, 2008; Henry \& Tator, 2010; Kumsa et al., 2014). Resistance is not only about resisting ABR but also resisting the ontology of forgetting which is defined as viewing Canada as an equity-based society despite the reality of ABR and other forms of oppression (Galabuzi, 2006; Henry \& Tator, 2010; Lawrence \& Dua, 2005). ABR brings about an understanding to this phenomenon of disproportionate streaming of Black people below their ability in the Ontario secondary school system. Additionally, Blackness is at the centre of this theory which is critical because Black bodies have different experiences in Canadian society because of their skin colour. 
Kumsa et al. (2014) declares that ABR is multifaceted and could mean an array of things. Kumsa et al. (2014) understand ABR to take at least three different forms including firstly, racism against Black people, secondly, racism Black people perpetuate also known as internalized racism, and the third being both the fight against $\mathrm{ABR}$ and racism perpetuated by Black people. In addition, applied streaming is an anti-Black racist practice that Black people experience, each Black woman in this study have various experiences and meanings of ABR. A key concept of $\mathrm{ABR}$ is exclusion which is the rejection experienced by Black individuals in institutions and policies because of dominant narratives, this is clear within the practice of streaming (Dei, 2008; Mullings, 2007). This is why Black bodies are bombarded on a daily basis with oppressive images of themselves by their oppressors which brings about internalization of these images and they start to see them as being true (Kumsa et al., 2014).

Whiteness and White supremacy are concepts of ABR and are attainable through identifying Blackness as a negative image (Dei, 1997; Delgado \& Stefancic, 2001; Fanon, 1967). Whiteness and White supremacy are the social construction of white skin being at the highest position which maintains power imbalances (Dei, 1997). Blackness is a concept of ABR as well and is a social construct for Black people and is used by the dominant class (White people) to dominate, oppress, and subordinate Black people as seen in the streaming practice (Delgado \& Stefancic, 2001; Fanon, 1967).

Black Canadian Feminism also informs this research study because it focuses on knowledge and theory by and about Black women residing in Canada (Amoah, 2007). In addition, a key concept with Black Canadian Feminism is taking a stance against patriarchy (specifically Black male patriarchy), misogynoir, and gender-based power relations within applied streaming in Ontario secondary schools (Prah, 2016; Neeganagwedgin, 2014, Neuman, 
2013). Walby (1989) declares that patriarchy is when males are seen as dominant in society and females are seen as subordinate. This is clearly shown within the literature of applied streaming with the focus or prioritization being on Black males and the silencing of Black female's experiences. Misogynoir is a specific type of misogyny that Black women experience, this is where race and gender both play a role in the oppression towards Black women (Bailey, 2013; Blair, 2014). Gender based power relations are dominant narratives about woman such as powerless, obedient, quiet, invisible and to be a man means powerful, outspoken, noticeable and in control (Walby, 1989). This stance against patriarchy, misogynoir, and gender-based power relations provides social justice by empowering Black women and letting them know that their stories are valuable and matter too (Prah, 2016; Neeganagwedgin, 2014, Neuman, 2013).

A key concept of Black Canadian Feminism is to explore Black women's lives and experiences from a historical context (Neeganagwedgin, 2014). This provides understanding of what is transpiring with Black women's lives and experiences currently in relation to applied streaming. Black Canadian Feminism is not utilized to homogenize Black women's experiences instead it is highlighting that different experiences of Black women occur in close proximity (Amoah, 2007). Black Canadian Feminism challenges assumptions and bias embedded in the Canadian Eurocentric educational system (Neeganagwedgin, 2014). This framework recognizes the challenges of Black women who are frequently othered by the dominant culture as well as the resistance and resilience displayed by Black women during the school system and after (Neeganagwedgin, 2014).

Black Canadian Feminism is critical in understanding how and why White European women differ in their experiences compared to Black women. Hill-Collins (1999) notes that this framework reveals Black women as being agents of knowledge, self-defined, independent people 
disrupting race, class, and gender oppressions. Black Canadian Feminism focuses on the issues with definitions about Black womanhood and the need for Black woman to create their own definitions and validate their own lived realities (Hill-Collins, 1999). This is why it is crucial to have Black women in this study to speak on their own narratives which validates their own lived realities because it is coming from the source who has experienced applied streaming. Furthermore, Black Canadian Feminism is used to transform Eurocentric practices such as streaming that impacts Black women and other marginalized groups (Wane, 2007).

Both ABR and Black Canadian Feminism focus on intersectionality or interlocking oppressions (Dei, 2008; Henry \& Tator, 2010; Kumsa et al., 2014; Hill-Collins, 1999; Pon et al., 2011; Prah, 2016; Neeganagwedgin, 2014). Intersectionality is an analytical tool utilized to understand the ways in which gender interlocks with other identities such as classism, racism, and so forth and how these intersections connect to oppression and privilege (Hill-Collins \& Blige, 2016). Interlocking oppressions or intersectionality enhances the understanding of oppressions that Black women face which was not addressed accurately by White feminism.

I believe that ABR and Black Canadian Feminism as theoretical frameworks best highlight Black women's experiences due to applied streaming in the Ontario secondary school system. This is because it highlights the difficulties that Black people endure in order to be successful in the Ontario secondary school system which is structured in a way to make Black people fail. Especially with focusing on Black women the system is structured in a way that makes them invisible and silences their stories compared to Black males. Both theoretical frameworks explore the historical context of this social issue and how it maintains, reinforces, and perpetuates ABR and imbalances of power when it comes to Whiteness versus Blackness, male versus female and so forth. 
ABR and Black Canadian Feminism emphasize that Black Caribbean and Black African communities mobilize via storytelling, poetry, counter-stories, art, dance, music, film, spoken word, research, the coming together of community. These are not only forms of activism for Black communities but also are considered counter knowledges that disrupt, critique, and challenge dominant knowledges that impact policies and everyday life (Dei, 2008; Delgado \& Stefancic, 2001; Fanon, 1967; Henry \& Tator, 2010; Kumsa et al., 2014; Prah, 2016). Black communities believe that these counter knowledges and forms of resistance are the only ways to transform systems such as the Ontario secondary school system that have been built on dominance and interlocking systems of oppression (Dei, 2008; Delgado \& Stefancic, 2001; Fanon, 1967; Henry \& Tator, 2010; Kumsa et al., 2014; Prah, 2016).

Both ABR and Black Canadian Feminism focus on the significance of partnerships and community within Black African and Black Caribbean cultures. Leseho \& Block (2005) and Rosenthal (2003) declared that it is a must for Black communities to form collaboration in order to portray resistance against the dominant class. There are many core values that both ABR and Black Canadian Feminism share. Some include equity, resistance, social justice, activism, empowerment, sense of community. Therefore, it was most appropriate to utilize both of these theoretical frameworks especially since I provided a path for Black women to share their experiences within the Ontario secondary school system. My hope is that this research about the overrepresentation of Black people in applied streams specifically the silencing of Black women and their experiences due to applied streams will contribute to activism, social justice, and consciousness raising within Black communities and Canadian society on a whole. Furthermore, I hope that this research will contribute to policy changes that desperately needs to be made within the Ontario secondary school system in order for equity to occur in streaming. 


\section{CHAPTER 4: METHODOLOGIES}

\section{Design}

With utilizing a qualitative design this research study will highlight two research questions. 1) What are Black women's experiences due to applied streaming in the Ontario secondary school system? 2) What are social workers role with respect to streaming in the Ontario secondary school system? The rationale for using a qualitative method to seek answers to these research questions is to capture a person centered, in depth, and humanized perspective by focusing on the voices of and by Black women in relation to their stories due to applied streaming (Carter \& Little, 2007; Padgett, 2017).

I interviewed two Black women who have experienced applied streaming and one Black professional within the educational system who has knowledge about streaming as well as the role of social workers. This study utilized pseudonyms to differentiate between participants/cocreators and to protect their confidentiality. Nate is the educational expert; identifies as a Black male. He worked as a schoolteacher in North Etobicoke, Rexdale, now he works in the union in an elected capacity, and mainly focuses on helping teachers, and political action. Lily identifies as a Black woman: In high school she was placed in applied science, resides in Etobicoke and recently completed a master's degree in social work. Anna identifies as a Black woman: grew up in a predominantly White and Asian neighbourhood, was automatically streamed in applied courses during high school, currently works in social services and resides in Woodbridge.

\section{Approaches of Inquiry}

\section{Narrative (Storytelling)}

A narrative (storytelling) approach and an arts-based approach are utilized in this research study in order to best capture the experiences and stories that link to applied streaming 
in the Ontario secondary school system from Black women along with an expert in the educational system. Narrative fits well with both Black Canadian Feminism and ABR frameworks because Afrocentric and Afro-Caribbean perspectives use narrative as a path to healing (Kumsa et al., 2014). Telling ones story about ABR provides healing in Black communities because its embedded in their cultures; you are telling your story as you live them; and narrative allows for the pain not to be harbored in one's body but rather uplift one's body (Kumsa et al., 2014). Narratives/storytelling is a natural form of expression for Black people because it is a long-standing tradition for Black Afro-Caribbean people (Greenidge \& Daire, 2010) and Black African people (Solórzano \& Yosso, 2002).

Narratives are also the best fit for this study because they are frequently utilized in studies that focus on experiences connecting to education (Connelly, \& Clandinin, 1990). Teachers and learners within or who have passed through the educational system are storytellers of their own narratives and other people's narratives (Connelly, \& Clandinin, 1990). Narrative begins with the experiences/stories as expressed and analyzes stories told (Creswell, 2013). Narrative focuses on spoken text which gives an account of an event/action which in this case would be experiences due to applied streaming (Creswell, 2013). Narratives are an important part of human culture because culture is represented through stories that we tell about ourselves (Fraser, 2004). Narratives also connect Black people to a sense of dignity, communities of belonging, and to healing which provides social justice for Black communities (Kumsa et al., 2014). Narratives validate knowledge coming from the source especially women (in this case Black women) who have been omitted from many research projects (Fraser, 2004). Narratives reflect reality and challenge taken for granted beliefs, and assumptions (Fraser, 2004). 
Furthermore, narratives/stories can be used to strengthen counter stories and go against dominant narratives and social actions (Fraser, 2004).

The type of narratives I sought are critical oral history narratives which gathers personal reflections of events and their causes and effects (Williams, 2019). Critical oral history is used to gather first person accounts from historical events (Williams, 2019). It is used to research into the lives of marginalized groups, such as, Black people, and in this case specifically Black women. Critical oral history focuses on the voice of the marginalized group rather than the researcher (Williams, 2019). This method empowered the participants/co-creators because it is giving them an opportunity to voice their perspectives which have been previously silenced (Williams, 2019). Critical oral history contributes to knowledge building and it is useful for activism as many are aware that histories can be erased and distorted or that there is the potential for histories to be erased and distorted (Williams, 2019).

\section{Arts-Based}

Participants/co-creators were asked to do an arts-based method and they had two weeks to complete it. There were two options provided the first one being an abstract drawing in any shape, symbol, word, and form. This option could be done with pen, pencil, pencil crayons, markers, crayons and so forth. The second option was choosing an online image. Both of these art-based methods connect to the last interview question which is "what does sharing your story mean for you". A phone debriefing occurred after participants/co-creators sent their art-based methods to me via email so that I would understand the meaning of their image in connection to their story about applied streaming.

The significance of the arts-based method (abstract drawing or online image) is to shift social relations (Nuvet et al., 2019) and contribute to social change (Nuvet et al., 2019). Art- 
based was used to allow for the expression of feelings whether it be difficult or empowering (Nuvet et al., 2019). Also, art-based was used to create community building, consciousness raising, and social action in relation to streaming (Nuvet et al., 2019). An Arts-based approach considers emotions, images, and symbols (Moffatt, 2019). In addition, participants/co-creators may not engage in their emotions fully for them to be resolved by only telling their story vocally, sometimes an artistic expression of the self is needed for that to occur (Moffatt, 2019). This artsbased method has provided critical reflection for participants/co-creators as they reflected about what storytelling meant for them and displayed those reflections by doing an abstract drawing on paper in any shape, word, form, or symbol or by choosing an online image (Moffatt, 2019). Also, this art goes against a singular explanation about experiences with streaming. This is why having both the vocal/written story with a visual allows for more explanation (Moffatt, 2019).

The art-based methods (abstract drawing or online image) and their meanings are included in this MRP underneath the findings section and they are shown again in the appendix section. The art pieces enrich the narratives because the visual provides more explanation to their written/vocal story, provides storytelling in two different forms to meet the needs of those reading who identify as visual learners or reading/writing learners. The meaning of the art pieces enrich the narratives because it provides a different form of activism, community building, consciousness raising, and resistance which disrupts, and critiques the dominant stories about Black women and applied streaming and brings to light the counter stories (Dei, 2008; Delgado \& Stefancic, 2001; Henry \& Tator, 2010; Kumsa et al., 2014; Nuvet et al., 2019). Also, artsbased method (abstract drawings and online images) enriches the narratives because it represents the artistic ways of knowing and doing embedded in Black communities (Dei, 2008; Delgado \& Stefancic, 2001; Henry \& Tator, 2010; Kumsa et al., 2014; Nuvet et al., 2019). 


\section{Participants}

The total number of participants/co-creators for this research study included three individuals (two Black women and one professional). Inclusion criteria for the two Black women included: Black women-identified individuals who were 18 years or older, having gone to an Ontario secondary school and were streamed into applied courses in the past, have been affected by applied streaming, and wanted to share their story of how applied streaming affected their experiences as Black women. Also, they live in Toronto or the greater Toronto areas, and were English speaking.

Exclusion criteria included: People who did not identify as Black women, and were under 18 years old, currently still attending an Ontario secondary school. In addition, did not attend an Ontario secondary school, has not been streamed into applied courses and was not affected by applied streaming, and did not want to share their story. Also, they did not live in Toronto or the greater Toronto areas, and not English speaking.

The third participant/co-creator included an educational expert. Inclusion criteria included: 18 years plus, works in the Ontario educational system, has knowledge about the effects of applied streaming for Black women and Black people. Additionally, the expert holds knowledge about social workers and their role or what it would look like in streaming within the Ontario secondary school system and wanting to share their story. In addition, broad understanding of governance within TDSB/greater Toronto school boards, direct experience with the interaction between social workers and educators, work within equity and diversity within TDSB/greater Toronto school boards, and research about Black student's experiences within the TDSB/greater Toronto school boards. Also, works in Toronto or the greater Toronto areas, and is English speaking. 
Exclusion criteria included: Below 18 years of age, did not work in the Ontario educational system, did not have knowledge about the effects of applied streaming for Black women and Black people. In addition, did not hold knowledge about social workers role or what it would look like in streaming within the Ontario secondary school system, and did not want to share their story. In addition, not having a broad understanding of governance within TDSB/greater Toronto school boards, no direct experience with the interaction between social workers and educators, did not work within equity and diversity within TDSB/greater Toronto school boards, and no research about Black student's experiences within the TDSB/greater Toronto school boards. Also, did not work in Toronto or the greater Toronto areas, and not English speaking.

\section{Recruitment Strategy}

The recruitment consisted of two separate parts including a recruitment email plus flyer attachment through email as well as another recruitment email. The recruitment email plus flyer attachment were for participants/co-creators that identify as Black women and met all other eligibility requirements. Please see flyer attachment in Appendix A. The recruitment flyer was sent out through email to the Master of Social Work program at Ryerson University. The flyer was a smart way to recruit people because the information for the study was on it but with an eye-catching design to make people stop and read. Ryerson's Master of Social Work program was a good place to do recruitment because my colleagues were also doing their own research and had connections to people in their network that were interested in my research study. Also, I had a better chance requesting the School of Social Work because I am an insider doing this research study for my Master of Social Work. I also recruited via email for the educational 
expert in the Ontario educational system. Please see attached email in Appendix B. This was the best option in order to be professional and to have a paper trail online for reminders.

\section{Data Collection}

First, I gathered the participants/co-creator's consent to be a part of this study. Please see Appendix C and D for consent forms. I intended to do face to face interviews but with the advent of COVID-19 I changed the method to phone interviews. With that being said with participants/co-creators consent I conducted individual in depth semi-structured phone interviews to collect data pertaining to their experiences while audio recording. I used semistructured phone interviews because I did not want to take away from the narratives by having an extensive amount of questions. In addition, I chose phone interviews in general to provide the space for me (the researcher) and participants/co-creators to build a rapport (Padgett, 2017). Also, with developing a rapport, participants/co-creators would want to share their experiences and I would be able to actively listen and show that I value what participants/co-creators have to say (Padgett, 2017). Black women told narratives in response to specific questions. For example, one question: How did applied streaming in the Ontario secondary school system affect your life experiences as someone who identifies as Black and a woman? Please see Appendix E for this interview guide. The educational expert told narratives in response to specific questions as well. For example, one question was: What role do social workers play with respect to streaming in the Ontario secondary school system? Please see Appendix F for this interview guide. when I needed clarification regarding participants/co-creator's answers I would ask probing questions. Also, if participants/co-creators felt uncomfortable or upset due to the questions asked in the phone interviews, I provided a list of services for emotional distress and counselling through email. Please see Appendix G for list of services. 


\section{Data analysis}

The phone interviews were transcribed manually verbatim and then analyzed line by line. Line by line analysis is literally going through the data line by line to gain detailed material (Fraser, 2004). It is good to be used when the participant number is small and it produces a wide range of analyses (Fraser, 2004). It was used to deconstruct the use of specific discourses and topics (Fraser, 2004). line by line analysis was used because narrative analyses should not be formulas or recipes because that will take away from the true narratives (Fraser, 2004). Line by line has no room to miss out on anything in the data because it captures all discourses and topics mentioned which ensures that narratives are portrayed in a correct manner. Fraser (2004) outlines seven phases for line by line analysis. I used these phases as a guide when analyzing the data.

Phase 1: listening to the stories, experiencing each other's emotions, this provides clues about meaning making (Borland, 1991; Kleinman \& Copp, 1993; Olson \& Shopes, 1991). Phase 2: transcribe the material, which offers a more accurate record of the interview, certain comments, and silences, may have meaning (Fraser, 2004). Phase 3: interpret transcripts, note specifics of each transcript, identify direction or contradictions in stories (Fraser, 2004). Phase 4: Examine stories for cultural, structural aspects and so forth (Fraser, 2004). Phase 5: link the personal with the political (Fraser, 2004). Phase 6: look for commonalities and differences among participants content (Fraser, 2004). Phase 7: write academic narratives about personal stories that helps to translate oral stories into written analysis (Fraser, 2004). The different discourses and topics found through these steps are put under different sections so that the readers can have a clear understanding of the analyses. After analyzing the data line by line, I asked the participants/co-creators if they wanted to see their specific transcripts to ensure that it is true to what they envisioned it to be before officially adding it to the final MRP. 


\section{CHAPTER 5: FINDINGS}

This chapter highlights the experiences of Black women who encounter applied streaming in the Ontario secondary school system. In addition, this chapter highlights the experience of an educational expert in the Ontario educational system with the role of social workers in relation to applied streaming. The names of participants/co-creators have been removed for the purpose of confidentiality and instead pseudonyms are used. The pseudonyms include Nate who is the educational expert, Lily who identifies as a Black woman, and Anna who identifies as a Black woman. Through data collection and line by line analysis there were ten topics overall, but I combined many together with other topics because they work hand in hand in the way how the stories were told. Once I did that, I broke the topics down into five sections which include: 1) Whiteness and ABR, 2) Misogynoir, 3) Educational and Employment barriers, 4) Social Workers Role, Politics, and Neoliberalism, 5) Resistance and Resilience.

Sections one to three are specific experiences for Lily and Anna of the study and their experiences with applied streaming. Nate who identifies as a Black male has not gone through these experiences in the way Black women have that is why I did not include anything that he mentioned for those topics except for one quote that will add context. Section four is specific to the experiences of Nate. Lily and Anna have not experienced direct interaction between social workers and educators in the way how Nate has that is why nothing is included from them in that section. Section five is specific to Nate, Lily, and Anna. I will touch on all ten topics as line by line analysis touches on every topic because every topic contributes to the correct portrayal of the narratives.

\section{Sources of Information}


In terms of the recruitment and sample size it played out according to plan. I was looking for two Black women to answer my first research question which is: What are Black women's experiences due to applied streaming in the Ontario secondary school system? I was looking for an educational expert who has knowledge about this topic and who has direct interaction with social workers and educators to answer my second research question which is: What are social workers role with respect to streaming in the Ontario secondary school system. I was able to gain all three eligible participants/co-creators needed for this study.

\section{Whiteness and ABR}

Lily and Anna shared their experiences with the various ways of how Whiteness and ABR occur in applied streaming and how that affects their lives. Nate spoke on budget cuts to guidance counsellors and how they are spread through with many schools and do not have time to give support to Black students. Lily and Anna spoke on guidance counsellors and teachers ignoring Black women and students in the streaming process because they "know best". They spoke about Black parents being ignored when they advocate for their children because they are looked at as challenging and aggressive. Lily and Anna touched on how guidance counsellors and teachers would say that applied courses are the best fit for them and the impact on selfesteem. Also, Black women feel like they cannot move from applied into academic and the need for more Black teachers was mentioned.

Nate: The guidance counsellor role has been significantly reduced meaning that due to budget cuts from the province we have had low numbers of guidance counsellors. Now the guidance counsellors are spread through, some have as many as ten schools so there are thousands of children that they have to oversee. So the fault maybe you will have to talk to the guidance counsellors to get their take but this is what I observe there is not enough time for them 
to give the kind of love and care and find them the services and the support that both they need and the parents need.

Lily: I think the students themselves are ignored, the reason why I say the students is because students sometimes do not want to be in applied science. I remember when I was going from middle school to high school I was placed in applied science and I did not want to be in applied science. I had to work that much harder to prove that I did not belong in applied science. It was not until $10^{\text {th }}$ grade when I went to a different school because I did move that is where I had to really push to be in the academic science. It is just that students are being ignored students are being streamed due to applied or even locally developed courses. Even sometimes their placed in the special education classrooms or the behavioural classrooms. They are being separated from their peers and the academic and mainstream levels. Sometimes students really do have aspirations and goals of what they really want to do with their lives. But its placed on the back burner because teachers and guidance counsellor's knowledge are seen as valuable.

I would say another group or people who are ignored are parents. Sometimes especially parents want what is best for their child but because at the same time the education system I read this in an article, or a report conducted by Carl James. The education system is connected to the child welfare system and child welfare system is connected to the legal system. Especially when you are a parent of colour you are scared to even go down to the school and advocate for what your child needs and wants. So, parents cave in and give in to what the school is doing with their child because they do not want to be deemed as rebellious and have a negative label about them as Black parents. Students and parents and the overall Black community.

When picking courses and picking your high school they kind of really sell this idea that applied programs/class are hands on, exciting, creative, or its about group and teamwork, you 
have to do less work. They really sell you this dream that applied is good. Not to discredit those who are in applied now or those who have been in applied programs. But they really try to convince you to go into applied programs because it is more fitting for you.

I believed that for a while but when I went into grade nine and took an applied science course, I did take other academic courses I think I took applied science and something else. I felt like I was not getting the experience that was promised to me I felt like I was not getting the experiences that I so rightfully deserved. I felt like I was kind of deceived, I felt like they had this low expectation of these gifts and abilities that I possess. They did not really see my full potential when they placed me in applied. When I was in academic, I felt like OMG (meaning oh my gosh) look at this I have been missing so much when I was in applied.

I just want to add with applied I think a lot of Black students especially Black women because I have seen this, and I still see this a lot of them do not know that they can actually move up. They can actually go from applied to academic I do not think a lot of them know or if they do know I feel like they were sold that dream so well that they have become so comfortable in applied.

Anna: I do think some students are ignored in the process especially if certain authority figures feel that they know what is best for the students. As well as some parents who might not understand the academic process or do not know the education system well are ignored when they try to ask questions or if they feel they know what is best for their child but they come across as aggressive or challenging then their automatically ignored because they are perceived as to be difficult when they are advocating for their students or their child. So definitely I feel that some parents are ignored in this process. 
I grew up in a predominantly Caucasian and Asian neighbourhood where most of my friends were streamed towards academic courses as opposed to my other friends who identified as African Canadian or of Black descent, we experienced discrimination where we were automatically streamed in applied courses. We were told that it was what we should be doing, this is what is best for you. Not really giving us an opportunity to either prove ourselves or you know or do anything extra or you know any testing to help guide us through that.

I definitely believe that the way students are streamed into different courses really makes a big impact on their self-esteem or their social standing where people are judged like oh you took applied courses oh you took academic courses.

I felt like knowing what I know now really helped provide some understanding in what I could put into words as a child what I was feeling like the microagressions that were there really created a barrier in terms of building rapport with certain staff or you know the guidance counsellors where they would make certain comments like you know passive aggressive looks or remarks. Just not understanding you know as someone who is an educator or a professional that you should not be doing that why would you do that. Now I do not feel comfortable to talk to you or that the comments are valid or sufficient.

I think there needs to be more Black staff in the education system. Growing up and even now supporting families with their children, just academic support, and school advocacy not seeing staff or teachers that look like Black people. As majority from what I find in the Toronto area and Etobicoke are teachers that are Italian, Portuguese, or Canadian Caucasian. It is one thing to say oh I took a cultural competence training, so I have a general idea of how to support children from these backgrounds. I think lived experience really makes a difference in supporting students that are Black. 


\section{Misogynoir}

Lily and Anna spoke about misogyny that Black women experience in terms of applied streams. Lily mentioned a specific type of misogyny that is more appropriate for Black women which is called misogynoir. This term focuses on the unique ways (combination of race and gender) that Black women are oppressed. Lily spoke about the disrespect for Black women's bodies, the offensive, and sexual comments towards Black women from Black males and teachers not doing anything to stop it. Lily and Anna touched on the better treatment and more attention that Black males got over Black women. Lily spoke about stereotypes towards Black women and how they transition from applied streams to post-secondary to employment and the need to conduct herself a certain way for these stereotypes to not be thrown her way. Anna touched on suggested career options and how they were female dominated jobs only.

Lily: I feel like I never really experienced too much of it yes here and there guys would make remarks when I was in the applied science course. I witnessed other Black girls being sexually harassed or I would not really say sexually harassed but they were not really respected, their bodies were not respected. Sometimes even the other boys who were of colour or racialized this could be their upbringing to there are so many intersections of it. They were loosely throwing around the B word and loosely throwing around inappropriate words or very offensive terms when it comes to speaking to Black girls. I feel like yes teachers said stop but they were not really putting their foot down and advocating for the safety and the well-being of Black girls in the classroom.

I found out that for some reason although Black boys and Black girls were in applied, I found that the teachers would kind of cater more towards the Black boys than the Black girls. I do not know why that is the case and sometimes even teachers would make remarks about Black 
girls. I cannot recall everything per say but I just know there was a difference in the treatment that Black boys got from teachers especially female teachers more so than Black girls getting certain treatments. I felt like as Black women we kind of had to tap into our own abilities and resilience to make things work for us. We were not getting the same attention; we were not getting the same resources although it is the same classroom. Just because we are in the same classroom does not mean resources are distributed equitably.

I do not know if this is a stretch or a reach, but I feel like even in jobs how Black women are treated young Black women. In jobs I find that the stereotype that keeps following and floating around is the "angry, rebellious Black woman". I feel like wherever I go whether it is a different academic institution even in university or in the work field I find that this stereotype is still being fed, it is still being prevailed, it is still being nourished, and it is still coming alive. I find that I have to conduct myself a certain way because this stereotype still exists about Black women. The stereotypes that exist about Black women include we are angry, we are bitter, we have, can I say we have daddy issues that is why we like to act out, we are inherently aggressive, and we are inherently hypersexual. The stereotypes that exist about Black women whether I am in university or the field I have to conduct myself a certain way when I am in certain spaces just because any time I step out of my character that stereotype or one of those stereotypes will be thrown at me already.

Anna: Specifically, as a Black female I feel like it affected how or what specific career options I could choose so thinking about the different options that were not available. But you know that was suggested gearing me towards oh but you know I think you would be good at this because you are a woman gearing towards more woman dominated careers if that makes sense. 
Such as nursing I remembered someone mentioned, daycare worker. Someone else mentioned it had something to do with acting or performing. Not that there is anything wrong with those careers but just streamed towards things like that. Not having people that looked like me give me feedback or give me you know guidance. When I attended a catholic school and all of the Black kids were you know put together or you know we were not regarded as part of the whole class. It is like oh those girls over there. It always felt like we were pointed out or just not being part of the whole classroom culture or made to feel like we were part of what was going on there.

For the Black males and Black females, the Black males for sure there was more attention towards them in terms of sports and political or more I do not know what word I am looking for but they were geared towards certain careers and courses and stuff. They were given more responsibilities in the school like school leadership they were the ones running you know the sports tournaments or the school dances, the school performances. So, in terms of that I would definitely say there is a difference between Black females and Black males.

\section{Educational and employment barriers}

Lily and Anna both spoke about lack of guidance and encouragement from teachers and guidance counsellors in applied streams that lead to educational and employment barriers for Black women. Lily spoke about how Black women are not encouraged to attend university and related that back to the Master of Social Work program she attended which did not have many Black women present. Anna spoke about not having guidance or encouragement which was needed and how that affected her navigation of post-secondary and where she ended up.

Lily: Now when you look at it a lot of Black women are not in university because they have been in applied learning for so long in high school it is like the only route, they can go is 
college or trades not really trades but more like apprenticeship programs. It is like they are not told, or they are not sold this belief that they can attend university. Even now in the master's program I do not see a lot of women who look like me, out of the forty or fifty or however many students I could just count on one hand of those who look like me in the program.

Anna: Applied streams definitely affected me in terms of what I wanted to do with myself after graduating. Throughout that process not getting the encouragement that I needed or the direction that I needed, the motivation that I needed to understand myself and then where I wanted to go. So just generally feeling like okay I am just another student I can pick whatever career just to get myself out of high school or just pick anything and you will figure it out later on. I feel like it really affected me once I got to grade twelve and I did not know specifically what I wanted to do I had a general idea wanting to work with children and families but did not know what options there were. When it came time to start applying for post-secondary school just applying to a whole bunch of colleges and then hoping for the best. So, it definitely did affect how I navigated the system and then where I ended up.

\section{Social Workers role, politics, and neoliberalism}

In this section Nate spoke about his insider knowledge around what social workers roles currently consist of in streaming which is not having a role. This is because they are not looked at as necessary and budget cuts from the government in terms of social workers so there ends up being one social worker with ten schools each. He mentioned what social workers role should consist of which is having a role in streaming, operating from a cultural relevant approach, and focusing on supporting every part of students specifically Black females and Black students.

Nate: So yes, definitely and again what has been so disappointing by this current provincial government, and previous ones too, not just to hate on the current one, we have seen 
significant cuts to our budget that has affected the number of social workers. So, in our last budget last year we cut a number of social workers from the system. So social workers it's the same thing we have social workers, we hire them, they might have ten schools each that have thousands of children right.

How do we teach; how do we help support every part of the child? That is where the social workers are crucial and that is the support, we need to take with all children right and of course I would argue with Black children, and Black female children specifically right.

So yeah, a social worker is key to helping children deal with family trauma, all the sorts of things that are going on in the home. But the problem is that we do not treat social work as necessary. If you ask me every school in Ontario certainly in Toronto would have a psychologist, a social worker, a child and youth worker, a special needs assistant which is like familiar with that neighbourhood.

That is what we need so social workers are a very, very important part of us closing the gap and making sure that our young, Black children, our young female Black children are successful. Of course, some people push back and say how are White woman who do not really understand the Black community, how are they going to help. Fair enough okay that is a fair argument, so we can talk about the social work department and the kind of training to make it culturally relevant. No argument there but at base having the social worker there that has the expertise and helping families and supporting families is a very crucial piece of the puzzle.

So, if we have governments that come in and give tax breaks to wealthy individuals and then turn around and say we do not have enough money to hire social workers then we should not be voting and putting them into power right.

\section{Resistance and Resilience}


Nate, Lily, and Anna spoke about ways in which they did not let different forms of oppression from applied streaming or the streaming practice stop them from advocating, moving forward, and creating transformative change. Also, their individual art pieces are shown with their connecting meanings underneath the art pieces because they all represent resistance and/or resilience in terms of applied streaming.

Nate: We opened up a school within a school and that school within a school the high school Afrocentric school it was done as grade nine and grade ten you would not be streamed. After a couple of years, they took that model and started spreading it around the board. I know that at least happened to two schools, I say that because I was part of the Afrocentric school advocacy when we were trying to open that.

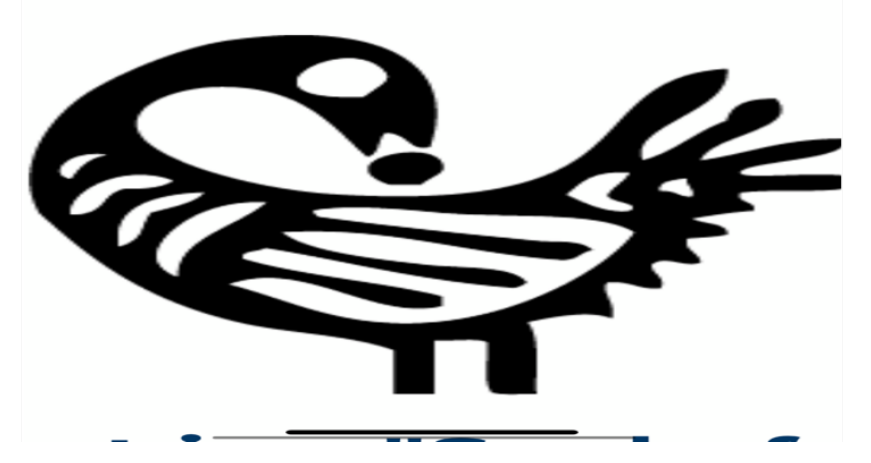

Looking backwards and learning how to move forward. Please see Appendix $\mathrm{H}$ for online art piece and meaning.

Lily: My story really made me see how resilient I am as a Black woman and how much I have accomplished in such a short span of time in my life. 
yeah, I am just happy because you know Black women can do anything if they put their minds, soul, and actions to it. They can do anything so I am very appreciative of my story and I hope that my story can empower others to do the same. If not the same as me to achieve more than they can ever imagine.

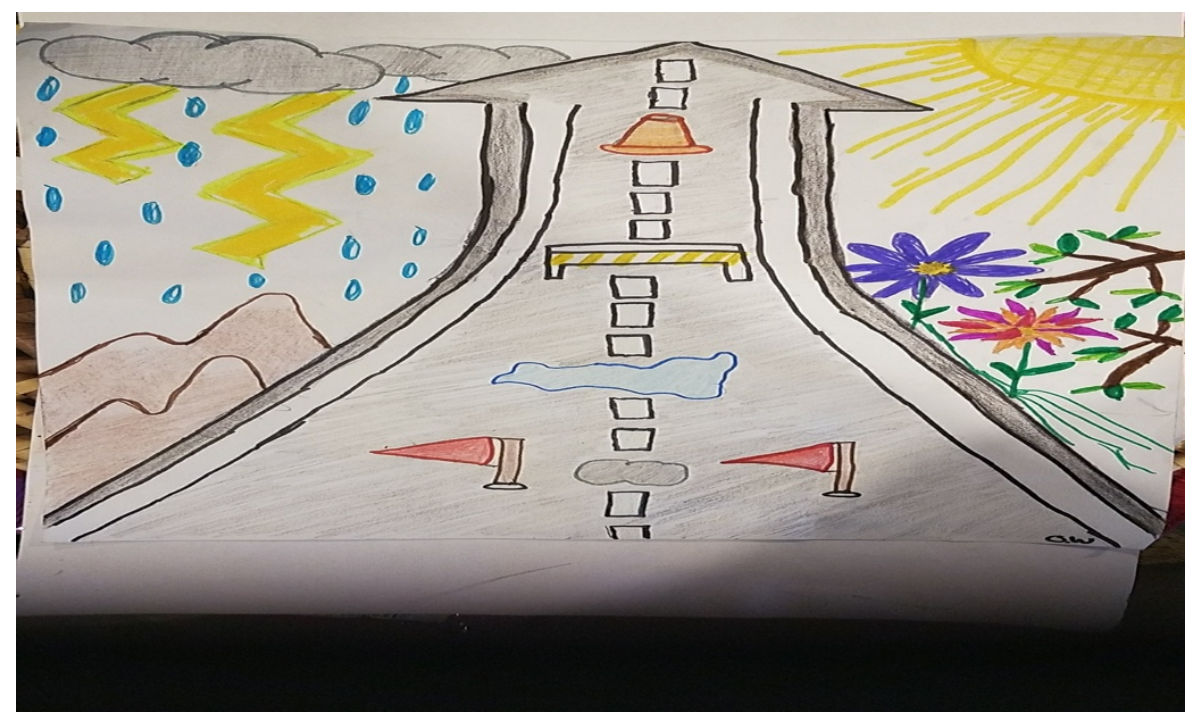

So that is pretty much it, good days, bad days and as I am still on this road to education, I came a long way that is why the road is very long and goes towards a certain direction. I came a long way, but I still have some ways to go when I am climbing up that educational ladder. Please see Appendix I for abstract art piece and meaning.

Anna: Sharing my story today really solidifies the work that I am doing now. I think it is a testament to my perseverance to my will to succeed. Just knowing that I have made it this far and can give back. I did not just make it this far to just sit here. 


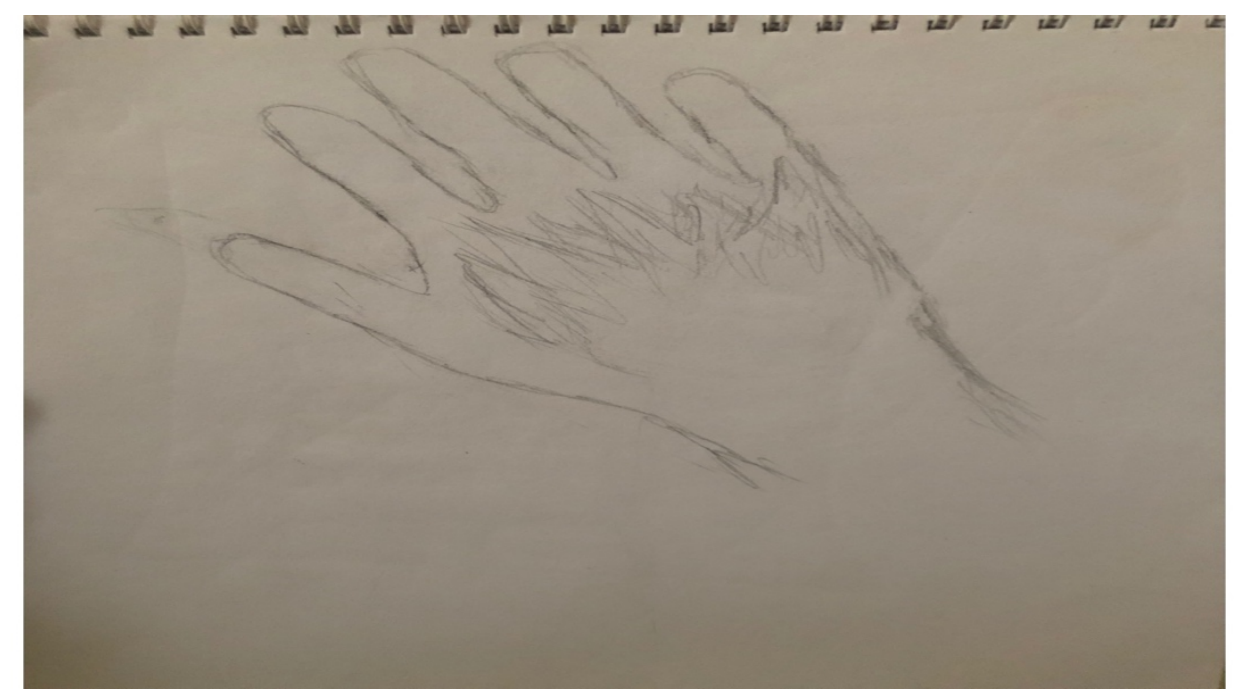

The image means being able to share my experiences to help highlight the academic system for Black girls and the importance of having a voice and position to share these experiences. This image is connected to me telling my story through a lived experienced that has a success story at the end and wanting to support Black girls in being able to overcome challenges in the academic system so that they may also have success stories and experiences. Please see Appendix J for abstract art piece and meaning.

I anticipated that the Black women would mention experiences of Whiteness and ABR, educational and employment barriers, and resistance and resilience in the data collection. This is consistent with my experiences as a researcher who identifies as a Black woman and went through applied streaming in the past. In contrast, I was surprised with the experiences of misogynoir due to applied streaming. I was surprised because I cannot remember personally experiencing misogynoir in secondary school during applied streams, but I recognize not every Black woman has the same experiences. Although I have experienced it otherwise such as in elementary school, middle school, post-secondary and employment. I was also shocked that history (slavery) was not brought up as history provides a better understanding of the experiences Black women have in applied streaming. 
I disagree with the piece about guidance counsellors, not because of the budget cuts or decrease of guidance counsellors in secondary schools. But because them not having time to support Black females and other Black students does not mean that their complicity in ABR and other forms of oppression are acceptable or supposed to occur in connection to applied streams. I agree with social workers playing a crucial role in streaming, in terms of supporting every part of Black women and Black students because they have the knowledge and expertise in supporting different communities. Also, I agree because through the findings and the literature review that support is definitely missing from guidance counsellors and teachers.

\section{Conclusion}

Nate shared experiences specific to social workers role, politics, and neoliberalism and resistance and resilience and Lily and Anna shared experiences of Whiteness and ABR, misogynoir, educational and employment barriers, and resistance and resilience. The findings offer an internal understanding of the issues that are transpiring within the Ontario secondary school system as it relates to applied steaming. The findings also offer ways to overcome these issues. The topics have been aided by literature which will be further explored during the discussion section. 


\section{CHAPTER 6: DISCUSSION}

In this chapter I will be interpreting results by looking at my findings through the lens of my theoretical frameworks which are ABR and Black Canadian Feminism. My interpretation will also include examining my findings within the context of my literature review. Then I will discuss how the findings and the interpretation of them answer my research questions which are 1) What are Black women's experiences due to applied streaming in the Ontario secondary school system? 2) What are social workers role with respect to streaming in the Ontario secondary school system?

\section{Whiteness and ABR}

Anna mentioned that in the Toronto and Etobicoke area most of the teachers are Italian, Portuguese, or White. The literature confirms that teachers, and guidance counsellors in Ontario are mostly White (James \& Turner, 2017). This is because White skin is considered at the highest standing in Canadian society (Dei, 1997). With their skin colour being at the highest standing allows for them to benefit with hiring, promotion, and influence in the Ontario secondary school system (Car \& Klassen, 1997). Also, with Whiteness being the highest standing allows for it being the norm, which means it is embedded in many areas of Canadian society such as the different levels of the educational system.

Whiteness is a concept of ABR and is achievable through identifying Blackness as a negative image meaning that Whiteness allows for the practice of ABR (Dei, 1997; Delgado \& Stefancic, 2001; Fanon, 1967). Blackness is a concept of ABR as well and is a social construct

for Black people and is utilized by the dominant class (White people) to oppress, and subordinate Black people (Delgado \& Stefancic, 2001; Fanon, 1967). 
The findings link to ABR because teachers and guidance counsellors who are mostly White look at Blackness as a negative image and use that reasoning to oppress Black students and parents (Dei, 1997; Delgado \& Stefancic, 2001; Fanon, 1967). For instance, the findings stated that teachers and guidance counsellors who are mostly White ignore Black students when it comes to their aspirations and goals because their knowledge is viewed as more valuable and Black students' knowledge is viewed as less valuable. Also, Black parents of students want to advocate for their Black children but are afraid because they do not want to be negatively labelled. Additionally, child welfare, police, and the Ontario secondary system are connected to push Black people into corrections (James \& Turner, 2017). So, parents are also afraid to speak up or for their children to speak up because they do not want to give the teachers and guidance counsellors a reason to call child welfare or the police (James \& Turner, 2017).

Oppression towards Black people can also look like the ABR concept of exclusion and rejection in institutions like Ontario secondary schools (Dei, 2008; Mullings, 2007). Lily and Anna both mentioned that guidance counsellors and teachers really sell and convince Black women and Black people in general to go into applied courses because it is more fitting for you. The literature confirms that guidance counsellors, and teachers frequently discourage Black people from taking academic courses and instead encourage them to take applied courses (Briggs, 2018; Carr \& Klassen, 1997; Chambers, 2009; Dei, 1997; Hope et al., 2015; James \& Turner, 2017; Neeganagwedgin, 2014; Schroeter \& James, 2015).

Being rejected and excluded from academic streams occurs because racist stereotypes are linked to Blackness such as being "unintelligent", "unable", and "mentally incompetent" to take or manage academic courses (Codjoe, 2006). The literature expands on how negative meanings associated with Blackness stem from history (slavery). White owners stopped slaves from 
learning how to read and write (Duhaney, 2010; James \& Turner, 2017). Back then Black people were forced to go to segregated schools, they could not go to all White schools because Blackness is looked at as inferior and Whiteness as superior (Duhaney, 2010; James \& Turner, 2017). This misrepresentation of Black people is perpetuated today as modern segregation but in the form of applied and academic courses (Kelly, 2009).

Furthermore, Black people feel excluded and rejected because according to the findings they do not get a chance to prove themselves or they have to fight to prove themselves to guidance counsellors and teachers. This ABR concept of exclusion and rejection allows Black people to not only experience racism against Black people but also experience another layer of ABR which is internalized ABR (Kumsa et al., 2014). The racist actions and statements from the teachers and guidance counsellors such as applied is more fitting for you, and really convincing Black people that it is less work, makes Black people believe that they have low expectations of them and therefore makes them believe that they are indeed inferior.

Lily mentioned that some Black women do not think they can go from applied to academic or they know they can but feel a sense of comfortability in applied. This happens because Black bodies are bombarded constantly with oppressive images of themselves by their oppressors, so they start seeing these negative images as the truth (Kumsa et al., 2014). When Black women and people look at these images as the truth, they become satisfied with being in applied courses (Tyson et al., 2005). Black women and people choose applied courses because they fear that they will fail academic courses (Tyson et al., 2005). Internalized ABR shapes Black people's identities by allowing them to feel less intelligent and lower their self-esteem (Kumsa et al., 2014; Tyson et al., 2005). 
In connection to the findings it is understandable that there are budget cuts in the education system meaning that guidance counsellors are spread thin and have multiple schools each and thousands of students to support. They may feel stressed and frustrated because they do not have the time. But that does not explain the overrepresentation of Black students being streamed mostly below their ability in applied courses and racist and negative behaviours that most of the guidance counsellors partake in towards Black students (Briggs, 2018; Carr \& Klassen, 1997; Chambers, 2009; Dei, 1997; Hope et al., 2015; James \& Turner, 2017; Neeganagwedgin, 2014; Schroeter \& James, 2015). The little time that they have with each student including Black students should be anti-oppressive not oppressive.

With anti-black racist behaviour from guidance counsellors and teachers' Black students are not going to feel comfortable to talk to them. Lily and Anna both mentioned feeling ignored, and Anna mentioned feeling uncomfortable and connecting that with the need for more Black staff as they would be more supportive due to lived experience. The literature confirms that having more Black staff can create a safe environment for Black students because they prevent racist stereotypes, have high academic expectations, go out of their way to support Black students (James \& Turner, 2017). As a result, Black students felt comfortable to seek support and speak up, gained high self-esteem and improved academically (James \& Turner, 2017).

\section{Misogynoir}

Lily mentioned that in applied streams they witnessed Black women experience offensive and sexual comments mainly from Black males such as the B word, and their bodies are not being respected and teachers did not do anything to stop it. The literature confirms that in terms of gender Black females face sexual stereotypes and perceptions pertaining to their low educational goals and achievements in school such as being in applied streams (Crenshaw et al., 
2015; Katshunga et al., 2020; Morris, 2007). Offensive and sexual comments occur because of a specific type of misogyny that Black women experience which is called misogynoir.

Misogynoir is a key concept of Black Canadian Feminism. Black Canadian Feminism acknowledges that misogynoir is the appropriate term for Black women. This is because it centers their experiences by taking into consideration the intersection of race (being black) and gender (being a woman) and accurately portrays how they both play a role in the oppression towards Black women (Bailey, 2013; Blair, 2014; Hill-Collins, 2000). Misogynoir also incorporates intersectionality which is another concept of Black Canadian Feminism which increases the understanding of interlocking oppressions that Black women face (Hill-Collins \& Blige, 2016). In connection to what Lily said above Black males said those sexual and offensive comments through Black male patriarchy which is where men are seen as superior and females as inferior (Walby, 1989). Patriarchy gives Black males ownership and control over Black women's bodies therefore they say what they want to say which reinforces misogynoir (Walby, 1989). Also, teachers not doing anything to stop these comments towards Black women shows their complicity in misogynoir and further perpetuates actions of misogynoir (Blair, 2014). Misogynoir and intersectionality do not just occur in applied streams towards Black women. The findings state that misogynoir can make its way from applied streams to postsecondary and even employment. Lily mentioned that the stereotypes that are constantly floating around are the angry Black woman, aggressiveness, hypersexual, these stereotypes make her feel the need to conduct herself a certain way otherwise these stereotypes will be thrown at her. The literature confirms that sexual and offensive stereotypes are indeed thrown towards Black women (Crenshaw et al., 2015; Katshunga et al., 2020; Morris, 2007). Additional literature confirms that Black women have negative reactions to these dehumanizing comments and 
therefore conduct their life in a way that does not get them labeled or limits them being labeled in order to receive acceptance in this White Eurocentric Canadian society (Johnson, 2013).

Additional literature expands by stating that negative images and comments said above stem from the term Jezebel which was created to prove the ideology of Black women being aggressive, not feminine, and lacking sexual control (Fasula et al., 2014). In addition, stereotypes and negative images of Black women stem from history (slavery) which is a concept of Black Canadian Feminism. White slave owners utilized different techniques of dehumanization such as stereotypes to be able to justify occupying African lands and Black bodies for capital gain (Morris, 2007). These techniques were utilized to justify their actions and to encourage Black bodies to justify their disobedience (Morris, 2007). Historical negative images reinforce and perpetuate stereotypes, historical stereotypes reinforce and perpetuate stigmatization of Black women currently in Canadian society (Fasula et al., 2014).

Misogynoir also plays out in applied streams through the different types of career options mentioned from teachers and guidance counsellors. Careers that are encouraged to Black women connect to their gender such as daycare worker, nursing, acting and so forth (Walby, 1989). This is because of gender based power relations and patriarchy which are concepts of Black Canadian Feminism. Males are seen as dominant which means that certain jobs that are more valued are looked at as male jobs (Walby, 1989). Females are seen as subordinate which means certain jobs that are not valued are seen as woman jobs (Walby, 1989). Patriarchy and gender-based power relations help to reinforce the misogynoir that Black women experience (Blair, 2014).

Lily and Anna stated that although there was both Black males and Black females in applied streams Black males received more attention and positive treatment. The literature confirms that Black males capture an overwhelming amount of attention which makes Black 
females invisible (Crenshaw et al., 2015; Orenstein,1994). This invisibility of Black females connects to a concept of Black Canadian Feminism which is patriarchy specifically Black male patriarchy. Hooks (2004) states that Black men are victims of White supremacist capitalist patriarchy which means they are taught by White men to connect being a man with control and dominance. Black male patriarchy allows for Black cisgender, heterosexual males to be seen as dominant and for Black females to be seen as subordinate (Walby, 1989). This is why Black males' needs are noticeable making them a priority and Black females needs are recognized as invisible and are pushed to the margins (Watson et al., 2012).

Black male patriarchy slightly differs from patriarchy because the racial oppression that Black males face is utilized as an excuse to ignore and to defend themselves against the oppression they perpetuate towards Black women such as saying negative comments to Black women and when receiving more attention not standing up for Black women (Webber, 2017). Black men utilize their power and control through patriarchy as a means to get back power taken from them in Canadian society (Dungee-Anderson \& Cox, 2000). Another reason that Black women were invisible and Black males received all the attention in applied streams is due to gender-based power relations a concept of Black Canadian Feminism. Dominant narratives about women include being invisible and for males' being noticeable so therefore these narratives play out in real life (Walby, 1989).

\section{Educational and Employment Barriers}

Lily declared that many Black women are not in university because of being encouraged to stay in applied courses for so long. Anna stated that being encouraged to stay in applied courses affected what she wanted to do after graduating. The literature confirms that applied streaming plays a role for Black people including Black women in terms of transitioning into 
post-secondary and finishing post-secondary (Kao \& Thompson, 2003). In addition, the literature confirms that staying in applied for a long time slows Black people down and makes a negative impact on their future (Kao \& Thompson, 2003). Furthermore, the overrepresentation of Black people who are usually being streamed under their ability into applied courses means more Black people are going to community college instead of university (Kao \& Thompson, 2003).

With no support, encouragement or guidance from teachers and guidance counsellors allows Black people especially Black women in applied streams to lack direction of where to go for post-secondary. The literature confirms that Black people do not get support and encouragement like other students and are left to their own to navigate the educational system and employment market (Briggs, 2018). The literature expands to state that this increases their chances of dropping out or being limited to precarious employment (Briggs, 2018).

The findings mentioned above connect to ABR and Black Canadian Feminism. These findings connect to two concepts of ABR which include one of the layers of ABR which is racism against Black people and rejection and exclusion which are part of this layer of ABR. Teachers and guidance counsellors do not encourage or support Black people in terms of navigating post-secondary because they view Blackness as a negative image such as being unintelligent and inferior (Dei, 1997; Delgado \& Stefancic, 2001; Fanon, 1967). Teachers and guidance counsellors believe in these deep-rooted historical stereotypes instead of actual evidence which reinforces the rejection and exclusion of Black people (James \& Turner, 2017). This also connects to the concept of patriarchy and gender power relations which is part of Black Canadian Feminism. Black women especially lack support with navigating post-secondary because teachers and guidance counsellors cater more to Black men (Crenshaw et al., 2015; Orenstein, 1994). This is because patriarchy and gender power relations suggest that Black men 
are dominant and powerful in the Black community and Black women are subordinate, so this is why Black women have a harder time with post-secondary and employment (Walby, 1989).

\section{Social Workers role, Politics, and Neoliberalism}

This section of the MRP may have less citations because there is no existing research on social workers role in relation to applied streaming, so Nate is giving us insider knowledge on this topic. Nate mentioned that social workers do not play a role in applied streaming because they are not seen as necessary. In addition, Nate stated that the current and recent governments have made cuts to the budget which limits the number of social workers in schools and as a result they might have ten schools each with thousands of students. The cuts to social workers transpire because of neoliberalism which discourages government support and places the responsibility of social services on to private services and individuals (Baines, 2017). Consequences of our Canadian neoliberal government system includes staff burnout which is occurring with social workers and accountability is towards the government rather than the communities served (Gibson et al., 2007). Having social workers in schools is political because if the government is making cuts to social workers then we as a Canadian society should not be voting them in power.

Nate stated that social workers are very crucial in terms of closing the gap and supporting every part of Black women and people to ensure that they are successful. Nate mentioned that a cultural relevant approach will need to be taken in terms of the selection of social workers, so not all White social workers but if there is some, they will have to take on that approach to actually be able to support Black women and people. Social workers relate to ABR and Black Canadian Feminism because they operate from anti-oppressive practices which are used to resist practices that support inequities such as these two theoretical frameworks in order to properly support Black women and people (Baines, 2017). 


\section{Resistance and Resilience}

Nate has contributed in displaying resistance by advocating for a de-streaming approach through an Afrocentric school in which only grade nine and ten have streams. Although there is still work to be done in terms of streaming, this model has made its way in some secondary schools already. Nate has shown resistance through sharing his storytelling and connecting artwork as well. Lily and Anna displayed resistance and resilience by sharing their storytelling and connecting artwork. This connects to the concept of mobilizing which is emphasized through ABR and Black Canadian Feminism. Mobilizing can look like storytelling, counter-stories, art, research, and the coming together of community which was shown throughout this MRP (Dei, 2008; Delgado \& Stefancic, 2001; Fanon, 1967; Henry \& Tator, 2010; Kumsa et al., 2014; Prah, 2016). These forms of mobilization showcase that in the face of oppression Black women and people are resilient. Additionally, these forms of mobilization are ways of activism for the Black community including Black women, they are also counter knowledges because these forms have critiqued, resisted, and challenged dominant stories about Black women and people in connection with applied streams (Dei, 2008; Delgado \& Stefancic, 2001; Fanon, 1967; Henry \& Tator, 2010; Kumsa et al., 2014; Prah, 2016).

The results answer my research questions which are 1) What are Black women's experiences due to applied streaming in the Ontario secondary school system? 2) What are social workers role with respect to streaming in the Ontario secondary school system? This is because as shown throughout the findings and discussion the two Black women explained their different experiences due to applied streaming such as, Whiteness and ABR, misogynoir, resistance and resilience and so forth. Also, the educational expert provided insider knowledge about social workers role currently and the importance of them playing a role in terms of streaming. 


\section{CHAPTER 7: IMPLICATIONS}

\section{Ethics}

In terms of ethics there was minor issues in securing REB approval. This is because I had to elaborate on certain sections of my ethics application. Also, I had to make minor changes throughout the ethics application due to the COVID-19 pandemic. For instance, I had to change my in-person interviews to phone interviews because participants/co-creators and my health and safety were a priority. I had to simplify my art method from abstract art on a canvas with paint to abstract drawing on paper with drawing materials like pen, pencil, markers and so forth because I did not want participants/co-creators to go out their way to buy materials. Also, I provided another art option of choosing an image online because I wanted to minimize stress especially during COVID-19. After I fixed these minor issues, I received ethics approval immediately.

\section{Strengths and Limitations}

This qualitative research provided an in depth understanding of Black women's experiences due to applied streaming and by focusing on Black women's voices it humanized my MRP (Carter \& Little, 2007). My research study filled a gap and provided the space for Black women to be finally heard. This research filled a gap by providing knowledge on social workers role in applied streaming and the significance of them playing a crucial role moving forward. This research was anti-oppressive by allowing Black women and the educational expert to share their experiences through narrative/storytelling which is a natural way of expression for Black Caribbean and African people and Black tradition (Greenidge \& Daire, 2010; Solórzano \& Yosso, 2002). Also, the Black women and educational expert provided art pieces which further explained their narratives but also was another way to provide resistance and activism for this 
social issue (Dei, 2008; Delgado \& Stefancic, 2001; Henry \& Tator, 2010; Kumsa et al., 2014; Moffatt, 2019; Nuvet et al., 2019; Prah, 2016).

This research filled another gap in current literature by operating from social work as a discipline and utilizing an ABR framework along with Black Canadian Feminism framework to accurately portray experiences of Black women due to applied streaming. In addition, these frameworks provided social justice by addressing and/or resisting ABR, Whiteness, misogynoir, Black male patriarchy and so forth in the Ontario secondary school system by calling out how it supports inequities regarding Black women (Clarke et al., 2015).

However, there are also limitations of this study which include time frame and requirements, sample size, page limit, what goes under the category of being a woman? biases in information, and COVID-19 along with ABR protests. The time frame and requirements for this MRP were quick and did not allow for any more than three participants/co-creators.

Consequently, the sample size is small with three participants/co-creators. The page limit seemed huge at first but once I analyzed the findings and completed the discussion of the findings, I realized that the space is limited, and I had to write in a way that still covered everything needed.

Black Canadian Feminism was the best theoretical framework to highlight these Black Canadian women's experiences however with the continuous use of the language "Black woman" who am I including and who am I leaving out? Is it only individuals born by birth as a female or does it take into consideration others who were not born by birth as a female but now identify as a female? This can be unclear and can leave some people confused by not knowing if this knowledge produced is empowering all individuals who identify as female/a woman or just some. Biases could have occurred in the information that participants/co-creators displayed. Lastly, this research study took place during the COVID-19 pandemic and the ABR protests that 
were reignited due to George Floyd's death. I was already stressed but even more with the pandemic and the ABR protests because of the changes I had to make to my research in relation to my art method and interviews. Also, I found it difficult at times to focus because of everything transpiring in the world which brought about a multiplicity of emotions for me.

\section{Future Research}

Although the research presented significant information about Black women's experiences and the role of social workers and the importance of social workers in applied streaming, there is still future research that could be incorporated. Future research could include interviewing both White and racialized guidance counsellors and teachers from a variety of secondary schools in Ontario which would add more perspectives to the issue. This would allow people to see similarities and differences between each Ontario secondary school in relation to streaming. In future expanding beyond two Black women's experiences to more Black women's experiences due to applied streaming to get an even better understanding of the issues on a wider scale would be paramount.

This research provided insider knowledge from an educational expert which provided important information especially about social workers role in streaming. However, for the future it would be interesting to hear from actual social workers who work in Ontario secondary schools and their perspectives of what social workers can do in terms of streaming. They would probably have much more to add as they know social work and how it can operate in educational settings. Possibly they can provide the Ontario secondary school system with ways to improve or better understand Black women and Black peoples needs. In addition, if social workers in Ontario secondary schools will be part of future research it is crucial to have a diversity such as ensuring that racialized social workers are included. Racialized workers may provide a unique 
point of view to this social issue by explaining the barriers, advocacy, and challenges when working with people that look like themselves.

\section{Implications}

My results and answers inform education and relevant policy. Ontario secondary schools should develop policy that requires a proper definition of ABR and Black Canadian Feminism and the forms of oppression that Black women and Black people go through such as misogynoir, Whiteness, Black male patriarchy and so forth (Oba, 2018). This is important in order to know what oppressions look like for Black women and people in relation to streaming, how to recognize, prevent, resist, and address it (Oba, 2018). This is part of ABR, and Black Canadian Feminism education and it must be informed by the perspectives of Black women and other Black people. Black elders or Black activist should come into Ontario secondary schools to provide trainings about Black history, colonialism, the oppressions mentioned above, and how to be an accomplice in eradicating oppression towards Black peoples (Oba, 2018). Also, Black communities should be involved in the creation and implementation of this ABR and Black Canadian Feminism policy to ensure it is feasible (Oba, 2018). There needs to be some form of accountability as well with this education and policy such as staff evaluation (Oba, 2018).

I mentioned Black Canadian Feminism in terms of education and relevant policy because equal attention to both Black females and Black males is needed in the Ontario secondary school system in relation to applied streaming (Oba, 2018). Eurocentric discourses and patriarchy specifically Black male patriarchy equates Blackness or ABR with Black masculinity which makes Black females invisible (Walby, 1989). Black females suffer from social exclusion differently than Black males and need solutions that address their concerns (Oba, 2018). 
Furthermore, my results and answers inform social work practice and research. My results and answers have proven that social workers need to play a role in streaming as Black women and people are not comfortable going to the teachers and guidance counsellors who encourage them to go into applied streams which are usually under their ability (James \& Turner, 2017). Social work practice can be present in many different areas including education and research that talks about social issues in education (OCSWSSW, 2020).

In order for social workers to play a role they need to be assigned to specific schools not ten schools each (Oba, 2018). It will be costly but at the same time it will be worth it (Oba, 2018). Ontario secondary schools need to understand that social workers are crucial in relationship building, healthy identity formation, anti-oppressive knowledge which addresses and resists ABR, Whiteness, misogynoir and so forth for Black women and people (Oba, 2018). This is different than teaching different school subjects and providing suggestions most times ridiculous suggestions about Black people's ability level. Teachers and guidance counsellors have their role, but social workers provide a specific and unique role in supporting every part of Black people and other students with their mental, emotional, social, psychological, and spiritual health (Oba, 2018). Social workers support with this social issue and its interlocking oppressions will aid in the success of Black women and people.

Also, a policy needs to be developed for increasing the number of Black teachers and social workers. Literature supports this view that Black people would benefit by having teachers that look like them (James \& Turner, 2017). I would add on social workers as well. When schools do not reflect certain groups, they perpetuate oppression to these groups (Oba, 2018). Black communities should help in the development of hiring criteria in order to gain Black teachers and social workers and ensure an anti-oppressive work environment (Oba, 2018). 
My results and answers from an ABR and Black Canadian Feminism framework inform social work practice, education, and research. An ABR framework was the best framework to be utilized because it is crucial in addressing the different layers of ABR, colonialism, Whiteness and White supremacy in Canadian society (Clarke et al., 2015). ABR framework puts ABR front and center because Black communities are the focus (Kumsa et al., 2014). ABR is used as a paradigm shift to see Black people as human beings and not criminals, aliens with no brains or to be feared (Oba, 2018). It is important to humanize Black people because they too have feelings and can experience oppression, when they are being ignored and treated unjustly (Oba, 2018).

Black Feminism was best to be utilized along with ABR because ABR or Blackness is associated many of the times with Black masculinity (Oba, 2018). Therefore, using ABR alone would not do justice for Black women. Black Canadian Feminism does many of the same things as ABR, but it does more specifically for Black women. Black Canadian Feminism allows a platform for Black women's voices to be amplified and heard. It takes a stance against patriarchy specifically Black male patriarchy, gender-based power relations, and misogynoir within applied streaming in Ontario secondary schools (Prah, 2016; Neeganagwedgin, 2014; Neuman, 2013).

There is an implication for ABR and Black Canadian Feminism frameworks in using an arts-based approach. Arts-based enriches Black women's narratives because it is used as another way of explaining their narratives, and another way to portray activism (Dei, 2008; Delgado \& Stefancic, 2001; Henry \& Tator, 2010; Kumsa et al., 2014; Moffatt, 2019; Nuvet et al., 2019; Prah, 2016). Art-based is specifically used as a counter knowledge for Black communities to critique, resist, and challenge dominant stories about Black women in applied streams and shedding light on counter stories (Dei, 2008; Delgado \& Stefancic, 2001; Henry \& Tator, 2010; Kumsa et al., 2014; Moffatt, 2019; Nuvet et al., 2019; Prah, 2016). 


\section{CHAPTER 8: CONCLUSION}

The issues presented in this MRP are not new they have been occurring for centuries in the United States and right here in Canada. It is clear that there is overrepresentation of Black people in applied streams which are usually under their ability level (James \& Turner, 2017). Many scholars have researched this social issue but unfortunately there has been few if any changes and some gaps. This means that more activism has to occur. With the prioritization of Black males' experiences in applied streaming this results in a huge gap in research around Black women's experiences especially through their own voices. There is no mention of social workers in current literature either and how they can be of important use. Also, no current literature has used an ABR framework to understand Black people's experiences which is mind blowing because streaming is an anti-Black racist practice. My research has contributed in filling in all these gaps, but it is just a starting point more has to be done in creating transformative change and equity for Black people in this case specifically Black women.

My research spoke about Black women's experiences due to applied streaming in the Ontario secondary school system such as Whiteness, ABR, misogynoir, educational and employment barriers, resistance and resilience. Whiteness is clearly shown in streaming because Whiteness is achievable by viewing Blackness in a negative light, Whiteness allows for ABR, they work hand in hand (Dei, 1997; Delgado \& Stefancic, 2001; Fanon, 1967). Whiteness helps to understand the overrepresentation of Black people streamed below their ability, and the negative treatment from guidance counsellors and teachers who are mostly White in Ontario. Misogynoir was explored by looking at the intersection of Blackness and being female, which are identities that Black women hold and how they connect to the oppressions or inequities that they experience in applied streams. Misogynoir played out in terms of Black male patriarchy and 
gender-based power relations. This is because of the fact that Black males gained more attention and support from teachers and guidance counsellors in applied streams. Also, Black males are looked at as superior and having control over Black women's bodies and that is why they feel the need to say negative comments and sexual stereotypes to them. Educational and employment barriers play out from being in applied streams because Black people specifically Black women do not get proper support and guidance in how to navigate employment or further education. But in the face of all of these oppressions Black women still find the strength to overcome, excel and succeed which makes them resilient. Black women sharing their narratives and artwork was also a way of resistance because they want action to be taken in terms of this social issue.

The educational expert spoke about having social workers as a necessity in terms of the streaming practice. This is because they bring anti-oppressive knowledge and expertise to the table that teachers and guidance counsellors do not possess. Social workers understand all of these oppressions that Black women and Black people face and would be of great support in terms of emotional, social, mental and spiritual health.

Lastly, this paper was not intended to perpetuate negative ideologies about Black women or Black people, and I have not claimed that every Black woman or person has these experiences. Also, this MRP is not intended in any way to show Black people specifically Black women in a negative light because of the focus on the oppressive experiences they have due to applied streaming. This is why I found it necessary to highlight positive experiences as well such as resistance and resilience in order to show the strength of Black women and Black people. The overall goal of this MRP is to illuminate the voices of Black women and their experiences due to applied streaming along with illuminating social workers role. Serious transformation needs to occur with the streaming practice in order for Black women and people to succeed. 


\section{Appendix A}

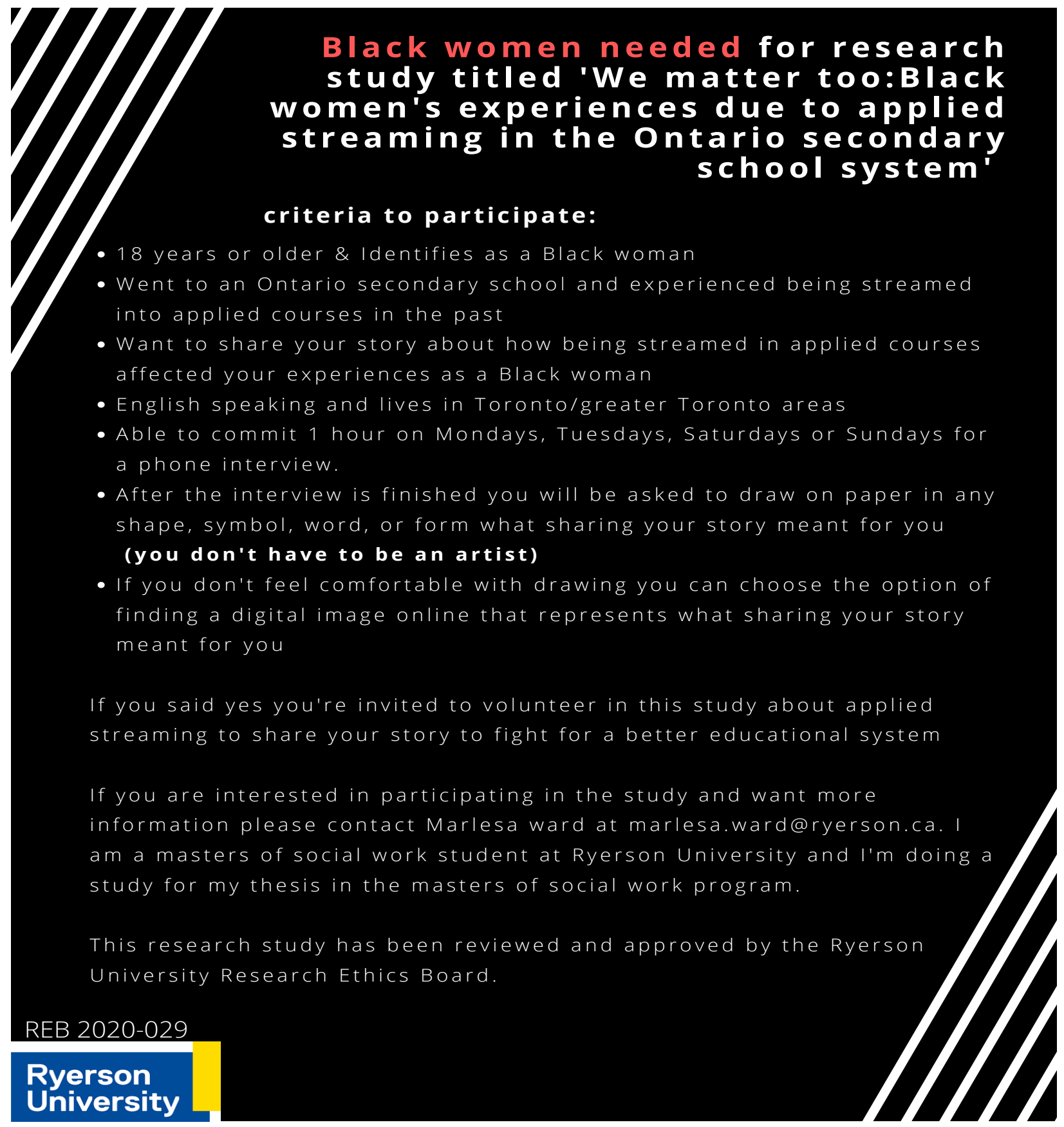




\section{Appendix B}

Hello,

My name is Marlesa Ward. I am a Master of Social Work student at Ryerson University in the School of Social Work. I am contacting you to see if you might be interested in participating in a research study.

This research is being done as part of my master's project and my supervisor's name is Dr. Ken Moffat a professor in the School of Social Work. The title of my research is We matter too: Black women's experiences due to applied streaming in the Ontario secondary school system. What is being looked at are the effects of applied streaming and how that connects to Black women's experiences/stories as there is a gap in research about this. Also, the role of social workers or what their role might look like within applied streaming as this is also a gap in research.

To participate you need to have the following criteria:

18 years or older, work within the Ontario educational system, have knowledge about the effects of applied streaming for Black women and Black people in general, can give information about social workers and their role or what it would look like in streaming within the Ontario secondary school system, broad understanding of governance within TDSB/greater Toronto area school boards, direct experience with the interaction between social workers and educators, work within equity and diversity within TDSB/greater Toronto area school boards, and research about Black student's experiences within the TDSB/greater Toronto area school boards. Also, you should want to share your story, work in Toronto or the greater Toronto areas, able to commit 1 hour in a phone interview, 1 time, on Mondays or Tuesdays, and is English speaking.

If you agree to volunteer, you will be asked to participate in sharing your story in a phone interview as mentioned above. Also, after the phone interview you will be asked to participate in drawing on a paper in any shape, symbol, word, or form of what sharing your story meant for you. By the way you don't have to be an artist for that part. If you feel uncomfortable with drawing you could choose the option of finding a digital image online that represents what sharing your story meant for you. Also, you will be cited if you want to be but if you don't want to be cited, I will not cite you.

Your participation will involve 1 session for a phone interview, it will be 1 hour. Also, as mentioned above choosing one of the two options of engaging in art.

The research has been reviewed and approved by the Ryerson University Research Ethics Board.

If you are interested in more information about the study or would like to volunteer please reply to this email marlesa.ward@ryerson.ca

Kind Regards, 
Marlesa Ward

Master of Social Work student/Researcher

REB 2020-029

Ryerson

University 


\section{Appendix C}

\section{Ryerson
University \\ Ryerson University \\ Consent Agreement}

You are being invited to participate in a research study. Please read this consent form so that you understand what your participation will involve. Before you consent to participate, please ask any questions to be sure you understand what your participation will involve.

\section{We matter too: Black women and their experiences due to applied streaming in the Ontario secondary school system}

INVESTIGATORS: This research study is being conducted by Marlesa Ward a Master of Social Work Student at Ryerson University. My supervisor is Dr. Ken Moffatt a professor from the School of Social Work at Ryerson University.

If you have any questions or concerns about the research, please feel free to contact Marlesa Ward at marlesa.ward@ryerson.ca

PURPOSE OF THE STUDY: The purpose of the study is to look at gaps in the research of applied streaming. It also looks at different things that happen to Black women because of being streamed in applied courses, and what the role of social workers are in the Ontario secondary school system in order to fight for a better educational system. The research study will focus at a full look of Black women's experiences due to applied streaming in the Ontario secondary school system. The number of participants being recruited/signed up for this study includes three people (two Black women and 1 professional). The study will include you as a Black woman, who is 18 years and older, went to an Ontario secondary school and have been streamed into applied courses in the past, have been affected by applied streaming, want to share your story, lives in Toronto or the greater Toronto areas, able to commit 1 hour, 1 time on Mondays, Tuesdays, Saturdays, or Sundays in a phone interview, and English speaking. This research is being done by a graduate student in the Master of Social Work program at Ryerson University so the results will be involved in a thesis.

WHAT YOU WILL BE ASKED TO DO [OR] WHAT PARTICIPATION MEANS: If you volunteer to participate in this study, you will be asked to do the following things:

- A phone interview to share your story about applied streaming in the Ontario secondary school system and how it affected your experiences as a Black woman

- You will participate in drawing on paper after the interview is complete, you will have 2 weeks to finish the drawing (you don't have to be an artist) 
- You will be creating an abstract drawing in any shape, symbol, word, or form of what sharing your story meant for you

- If you do not feel comfortable you can choose the option of finding a digital image online that represents what sharing your story meant for you

- Then after the 2 weeks you will be asked to send your artwork (drawing or digital image) as an email attachment to me. We will do a phone debrief of the meaning of the image. I will use the image along with the other participants images so that it can be the visual that goes with your written/oral story.

\section{What kind of study and where will it be?}

The research study will be in the form of a qualitative study. A qualitative study is used when little or nothing is known about a topic, or when the researcher wants to have a complete understanding of a person's experience (Faulkner \& Faulkner, 2016). The study will be done through phone interview style. The location of where the research will be done will be in a private closed room that allows for confidentiality and that meets your needs. You will be interviewed in total 1 time, on Mondays, Tuesdays, Saturdays, or Sundays depending on your availability, the interview will be 1 hour. You will be asked questions related to your experiences. For example, how did applied streaming in the Ontario secondary school system affect your life experiences as someone who identifies as Black and a woman?

\section{Demographic Collection}

Information collected from you will be:

- What is your Name?

- Are you 18 or over in age?

- What is your gender and racial background?

- Which province and city do you live in?

- What is your email address/ and or phone number?

\section{Will the research findings be available?}

The research findings will be available through a link to the Ryerson Digital Repository, where all MRP's including my MRP will be uploaded after completion, so that you can get the results on your own time.

\section{POTENTIAL BENEFITS:}

The potential benefits of this study could be contributing to further activism/support and awareness for this issue, in Canadian society, for Black communities, and Black peoples through the sharing of participants stories and research findings.

My aim for my research is to further contribute to anti-oppressive practice, anti-Black racism, and Black feminism by spreading awareness and further contributing to activism regarding this issue of applied streaming being targeted to Black peoples and the fact that Black women's 
voices are limited within this research compared to Black males. Another goal or expected outcome is that I want to address that social workers role is not spoken about in the research/literature regarding the streaming process within schools when they are also present in schools. I want to gain information about this from one of my participants who will be an expert in the Ontario secondary school system. This information about social workers will add to the research on streaming which will better support the efforts of helping Black women and other Black people through this process. However, I cannot guarantee that you will receive this benefit or any benefits from participating in this study.

\section{WHAT ARE THE POTENTIAL RISKS TO YOU AS A PARTICIPANT}

This study involves potential risks which can be looked at as low risks because they can be easily managed by me providing appropriate ways for these risks to stay low. You may feel uncomfortable or upset due to the way questions are asked in the phone interview and sharing stories. You might look back on uncomfortable memories due to these questions. I will let you know that there is a potential for this to happen and if you start to feel these feelings, you may skip answering a question or stop participation, either temporarily or permanently. This topic is about your narrative/story so if at any time it causes psychological risks such as anxiety or emotional distress you or me (the researcher) may decide to temporarily stop the study or permanently end the study. Also, before and after the phone interview process I will send through email a list of services for counseling and emotional distress so that if you need them, they are there. Also, if you share any information that can potentially be a threat to you or anyone else such as to harm yourself or others, I have a professional duty to report the information to legal authorities. I will make sure that you have a different name in the research study to protect your personal identity.

\section{CONFIDENTIALITY:}

As mentioned, before you will be asked to provide demographic information such as your name, age, gender, racial background, what province and city you live in. All of this information except for race, gender, and province/city will be kept confidential and won't be mentioned in the study. Race, gender, and province/city are important parts to mention in the study because of the topic and the research questions plus it provides context. The artwork (abstract drawings or digital images) will be photographed (the artwork will be digitized) so that they can be included in the MRP. With that being said the artwork will have no identifying information as only the art on the paper or the digital image will be presented, and nobody will know which art piece belongs to who as only the fake names will be attached to them. Any other information that you provide for the study will be kept confidential. However, if at any time you provide any information that can potentially be a threat to you or anyone else such as to harm yourself or others, I have a professional duty to report the information to legal authorities. For the purpose of the study you may use a different name instead of your real name to protect your identity in publishing material. While the study is in progress the consent forms, and interview transcripts will be stored online on the Ryerson Google Shared Drive. Only those involved with the research such as myself (the researcher) and my supervisor will have access to the information collected. Following completion of phone interviews, digitized art, and audio recordings will go on the 
computer and will be stored on the Ryerson Google Shared Drive, since it is secure and encrypted, minimizes the risk of data being accessed by unauthorized individuals, and facilitates the sharing of data without need for transportation or duplication of data. The raw audio recordings will be deleted following transcription and verification. The data will be stored for a period of 1 year and will be available to you before the data analysis stage. Data analysis is an ongoing process that involves breaking data into meaningful parts for the purpose of looking at them (Meerai, 2018). With that being said you have a right to review/edit the recordings and/or transcripts as it is your information and should be what you want to be presented. Transcripts will be sent through email with an attachment to a file that is password protected.

\section{INCENTIVES FOR PARTICIPATION:}

As a participant you will not be paid to participate in this study.

\section{COSTS TO PARTICIPATION:}

There is no reimbursement (being paid back what you spent) because there are no transportation costs involved in this study.

\section{COMPENSATION FOR INJURY:}

By agreeing to participate in this research, you are not giving up or waiving any legal right in the event that you are harmed during the research.

\section{VOLUNTARY PARTICIPATION AND WITHDRAWAL:}

Participation in this study is completely voluntary. You can choose whether to be in this study or not. If any question makes you uncomfortable, you can skip that question. You may stop participating or withdraw at any time right up until the end of the project which is June 1. If you choose to stop participating, you may also choose to not have your data included in the study. The data will be removed at your request. But, if for some reason you want it to still be used then I will obey your wish. Your choice of whether or not to participate will not influence your future relationship with Ryerson University or the investigator Marlesa Ward or my supervisor Dr. Ken Moffatt involved in the research. In the case that you are using harmful language or violent behaviours towards yourself or me (the researcher), your involvement may be ended without the regard for your consent.

QUESTIONS ABOUT THE STUDY: If you have any questions about the research now, please ask. If you have questions later about the research, you may contact Marlesa Ward (Master of Social Work Student/researcher) at marlesa.ward@ryerson.ca or my supervisor Dr. Ken Moffatt at kmoffatt@ryerson.ca

This study has been reviewed by the Ryerson University Research Ethics Board. If you have questions regarding your rights as a participant in this study please contact:

Research Ethics Board

c/o Office of the Vice President, Research and Innovation Ryerson University 
350 Victoria Street

Toronto, ON M5B 2K3

416-979-5042

rebchair@ryerson.ca 
We matter too: Black women and their experiences due to applied streaming in the Ontario secondary school system

\section{CONFIRMATION OF AGREEMENT:}

Your signature below indicates that you have read the information in this agreement and have had a chance to ask any questions you have about the study. Your signature also indicates that you agree to participate in the study and have been told that you can change your mind and withdraw your consent to participate at any time. You have been given a copy of this agreement. You have been told that by signing this consent agreement you are not giving up any of your legal rights.

Name of Participant (please print)

Signature of Participant

Date

I agree to be audio-recorded for the purposes of this study. I understand how these recordings will be stored and destroyed.

Signature of Participant

Date 


\section{Appendix D}

\section{Ryerson University}

\section{Ryerson University \\ Consent Agreement}

You are being invited to participate in a research study. Please read this consent form so that you understand what your participation will involve. Before you consent to participate, please ask any questions to be sure you understand what your participation will involve.

We matter too: Black women and their experiences due to applied streaming in the Ontario secondary school system

INVESTIGATORS: This research study is being conducted by Marlesa Ward a Master of Social Work Student at Ryerson University. My supervisor is Dr. Ken Moffatt a professor from the School of Social Work at Ryerson University.

If you have any questions or concerns about the research, please feel free to contact Marlesa Ward at marlesa.ward@ryerson.ca

PURPOSE OF THE STUDY: The purpose of the study is to look at gaps in the research of applied streaming. It also looks at different things that happen to Black women because of being streamed in applied courses, and what the role of social workers are in the Ontario secondary school system in order to fight for a better educational system. The research study will focus at a full look of Black women's experiences due to applied streaming in the Ontario secondary school system. The number of participants being recruited/signed up for this study includes three people (two Black women, and one professional). The study will include you as a professional in the field, who is 18 years and older, works within the Ontario educational system, has knowledge on the effects of applied streaming for Black women and Black people, can give information about social workers and their role or what it would look like in streaming within the Ontario secondary school system, broad understanding of governance within TDSB/greater Toronto school boards, direct experience with the interaction between social workers and educators, work within equity and diversity within TDSB/greater Toronto school boards, and research about Black student's experiences within the TDSB/greater Toronto school boards. Wants to share your story, works in Toronto or the greater Toronto areas, able to commit 1 hour, 1 time on Mondays or Tuesdays in a phone interview, and is English speaking. This research is being done by a graduate student in the Master of Social Work program at Ryerson University so the results will be involved in a thesis. 
WHAT YOU WILL BE ASKED TO DO [OR] WHAT PARTICIPATION MEANS: If you

volunteer to participate in this study, you will be asked to do the following things:

- A phone interview to share your story about what you've seen and the effects that happen to Black people and specifically Black women with being streamed into applied courses

- Share information about social workers and their role in streaming within the Ontario secondary school system or what that might look like

- You will participate in drawing on paper after the interview is complete, you will have 2 weeks to finish the drawing (you don't have to be an artist)

- You will be creating an abstract drawing in any shape, symbol, word, or form of what sharing your story meant for you

- If you do not feel comfortable you can choose the option of finding a digital image online that represents what sharing your story meant for you

- Then after the 2 weeks you will be asked to send your artwork (drawing or digital image) as an email attachment to me. We will do a phone debrief of the meaning of the image. I will use the image along with the other participants images so that it can be the visual that goes with your written/oral story.

\section{What kind of study and where will it be?}

The research study will be in the form of a qualitative study. A qualitative study is used when little or nothing is known about a topic, or when the researcher wants to have a complete understanding of a person's experience (Faulkner \& Faulkner, 2016). The study will be done through phone interview style. The location of where the research will be done will be in a private closed room that allows for confidentiality and meets your needs. You will be interviewed in total 1 time on Mondays or Tuesdays depending on your availability, the interview will be 1 hour. You will be asked questions related to your experiences. For example, What role do social workers play with respect to streaming in the Ontario secondary school system? Or if no role is played or it is not a proper role, what do you envision social workers role to be?

\section{Demographic Collection}

Information collected from you will be:

- What is your Name?

- Are you 18 or over in age?

- Which province and city do you work in?

- What is your place of employment within the educational system?

- What is your email address/ and or phone number?

\section{Will the research findings be available?}


The research findings will be available through a link to the Ryerson Digital Repository, where all MRP's including my MRP will be uploaded after completion, so that you can get the results on your own time.

\section{POTENTIAL BENEFITS:}

The potential benefits of this study could be contributing to further activism/support and awareness for this issue, in Canadian society, for Black communities, and Black peoples through the sharing of participants stories and research findings.

My aim for my research is to further contribute to anti-oppressive practice, anti-Black racism, and Black feminism by spreading awareness and further contributing to activism regarding this issue of applied streaming being targeted to Black peoples and the fact that Black women's voices are limited within this research compared to Black males. Another goal or expected outcome is that I want to address that social workers role is not spoken about in the research/literature about the streaming process within schools when they are also present in schools. I want to gain information about this from one of my participants who will be an expert in the Ontario educational system. This information about social workers will add to the research on streaming which will better support the efforts of helping Black women and other Black people through this process. However, I cannot guarantee that you will receive this benefit or any benefits from participating in this study.

\section{WHAT ARE THE POTENTIAL RISKS TO YOU AS A PARTICIPANT}

This study involves potential risks which can be looked at as low risks because they can be easily managed by me providing appropriate ways for these risks to stay low. You may feel uncomfortable or upset due to the way questions are asked in the phone interview and sharing stories. You might look back on uncomfortable memories due to these questions. I will let you know that there is a potential for this to happen and if you start to feel these feelings, you may skip answering a question or stop participation, either temporarily or permanently. This topic is about your narrative/story so if at any time it causes psychological risks such as anxiety or emotional distress you or me (the researcher) may decide to temporarily stop the study or permanently end the study. Also, before and after the interview process I will send through email a list of services for counseling and emotional distress so that if you need them, they are there. Also, if you share any information that can potentially be a threat to you or anyone else such as to harm yourself or others, I have a professional duty to report the information to legal authorities. There may be financial risk as you will be speaking from a professional place regarding the issues with the practice of streaming and how this practice affects Black women and people. I will make sure that you have a different name in the research study to protect your personal identity. Also, for demographic information I will make sure that it is clear for the place of employment section that I do not want the name of the Ontario secondary school as that will reveal personal identity. Instead I would just want to know that you are working at one or closely with one. 


\section{CONFIDENTIALITY:}

As mentioned, before you will be asked to provide demographic information such as your name, age, what city and province you work in, place of employment within the educational system. All of this information except for province/city you work in and place of employment within the educational system will be kept confidential and won't be mentioned in the study. Province/city and place of employment are important parts to mention in the study because of the topic and the research questions plus it provides context. The artwork (abstract drawings or digital images) will be photographed (the artwork will be digitized) so that they can be included in the MRP. With that being said the artwork will have no identifying information as only the art on the paper or the digital image will be presented, and nobody will know which art piece belongs to who as only the fake names will be attached to them. Any other information that you provide for the study will be kept confidential. However, if at any time you provide any information that can potentially be a threat to you or anyone else such as to harm yourself or others, I have a professional duty to report the information to legal authorities. For the purpose of the study you may use a different name instead of your real name to protect your identity in publishing material. While the study is in progress the consent forms, and interview transcripts will be stored online on the Ryerson Google Shared Drive. Only those involved with the research such as myself (the researcher) and my supervisor will have access to the information collected. Following completion of phone interviews, digitized artwork, and audio recordings will go on the computer and will be stored on the Ryerson Google Shared Drive, since it is secure and encrypted, minimizes the risk of data being accessed by unauthorized individuals, and facilitates the sharing of data without need for transportation or duplication of data. The raw audio recordings will be deleted following transcription and verification. The data will be stored for a period of 1 year and will be available to you before the data analysis stage. Data analysis is an ongoing process that involves breaking data into meaningful parts for the purpose of looking at them (Meerai, 2018). With that being said you have a right to review/edit the recordings and/or transcripts as it is your information and should be what you want to be presented. Transcripts will be sent through email with an attachment to a file that is password protected.

\section{INCENTIVES FOR PARTICIPATION:}

As a participant you will not be paid to participate in this study.

\section{COSTS TO PARTICIPATION:}

There is no reimbursement (being paid back what you spent) because there are no transportation costs involved in this study

\section{COMPENSATION FOR INJURY:}

By agreeing to participate in this research, you are not giving up or waiving any legal right in the event that you are harmed during the research.

\section{VOLUNTARY PARTICIPATION AND WITHDRAWAL:}


Participation in this study is completely voluntary. You can choose whether to be in this study or not. If any question makes you uncomfortable, you can skip that question. You may stop participating or withdraw any time right up until the end of the project which is June 1. If you choose to stop participating, you may also choose to not have your data included in the study. The data will be removed at your request. But, if for some reason you want it to still be used then I will obey your wish. Your choice of whether or not to participate will not influence your future relationship with Ryerson University or the investigator Marlesa Ward or my supervisor Dr. Ken Moffatt involved in the research. In the case that you are using harmful language or violent behaviours towards yourself or me (the researcher), your involvement may be terminated without the regard for your consent.

QUESTIONS ABOUT THE STUDY: If you have any questions about the research now, please ask. If you have questions later about the research, you may contact Marlesa Ward (Master of Social Work Student/researcher) at marlesa.ward@ryerson.ca or my supervisor Dr. Ken Moffatt atkmoffatt@ryerson.ca

This study has been reviewed by the Ryerson University Research Ethics Board. If you have questions regarding your rights as a participant in this study please contact:

Research Ethics Board

c/o Office of the Vice President, Research and Innovation

Ryerson University

350 Victoria Street

Toronto, ON M5B 2K3

416-979-5042

rebchair@ryerson.ca 
We matter too: Black women and their experiences due to applied streaming in the Ontario secondary school system

\section{CONFIRMATION OF AGREEMENT:}

Your signature below indicates that you have read the information in this agreement and have had a chance to ask any questions you have about the study. Your signature also indicates that you agree to participate in the study and have been told that you can change your mind and withdraw your consent to participate at any time. You have been given a copy of this agreement. You have been told that by signing this consent agreement you are not giving up any of your legal rights.

Name of Participant (please print)

Signature of Participant

Date

I agree to be audio-recorded for the purposes of this study. I understand how these recordings will be stored and destroyed.

Signature of Participant

Date 


\section{Appendix E}

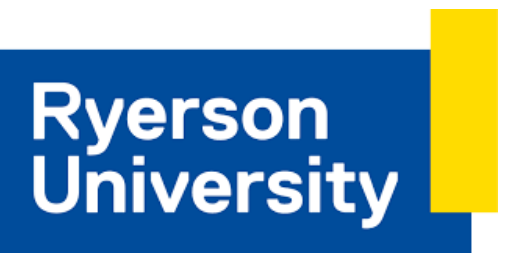

\section{Semi-Structured Interview Guide for 2 Black Women}

Researcher: Marlesa Ward

Date:

Participant/Co-creator:

Opening questions before study (small chat)

1. How is the weather now outside?

2. Tell me a bit about yourself? (only if you feel like it)

3. Do you have any questions about the research or in general?

\section{Study Questions}

1. What do you understand about the streaming process specifically for secondary schools?

2. Who plays a role in the decision making of the streaming process?

3. Do you think anyone is ignored from this decision-making process? If yes or no, please elaborate?

4. What does it mean to be in applied versus academic courses? Or what meaning did you put with applied versus academic courses?

5. How did applied streaming in the Ontario secondary school system affect your life experiences as someone who identifies as Black and a woman? Please explain in detail

6. What did sharing your story today mean for you?

Note: Answers for question 6 will be drawn on paper in any shape, symbol, word, form or will be represented by an online digital image and will be the visual that goes with their written/oral story. Also, probing questions may happen in between if participants get stuck. 


\section{Appendix F}

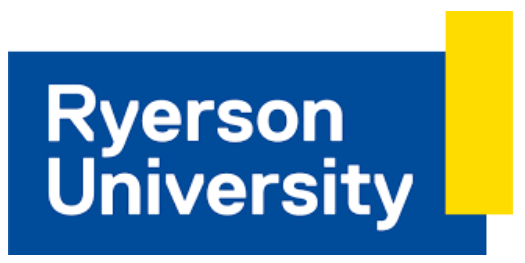

\section{Semi-Structured Interview Guide for professional}

Researcher: Marlesa Ward Date:

Participant/Co-creator:

Opening questions before study (small chat)

4. How is the weather now outside?

5. Tell me a bit about yourself? (only if you feel like it)

6. Do you have any questions about the research or in general?

Study Questions

7. What is the streaming policy and what does it look like in practice specifically for secondary schools?

8. Do you think anyone is ignored from the decision-making process when it comes to streaming? If yes or no, please elaborate?

9. From your knowledge and what you've seen how does applied streaming affect Black people's experiences? Can I get your thoughts on Black women specifically?

10. What role do social workers play with respect to streaming in the Ontario secondary school system? If no role is played ask "what do you envision their role to be?"

11. What did sharing your story today mean for you?

Note: Answers for question 6 will be drawn on paper in any shape, symbol, word, form or will be represented by an online digital image and will be the visual that goes with their written/oral story. Also, probing questions may happen in between if participants get stuck. 


\section{Appendix G}

\section{List of Services for Counselling and Emotional Distress}

\section{$\underline{\text { Family Service Toronto }}$}

\section{Locations \& Contact information}

Church Street Office 355 Church Street Toronto, ON, Canada

Contact 416-595-9618

FST West Toronto Office 128A Sterling Rd, Suite 202, Toronto

Contact 416-780-1106

FST East Toronto Office Victoria Park Hub 1527 Victoria Park Avenue, Scarborough Contact 416-595-9618

- Free confidential walk in counselling every Wednesday from 3:30-7:30

- Trauma informed therapy and emotional focussed therapy

Website: https://familyservicetoronto.org/our-services/programs-and-services/walk-in-clinic/

\section{Distress Centres of Greater Toronto}

\section{Help Line}

Contact 416-408-4357 or text 45645

- Open 24 hours a day, 7 days a week, 365 days a year for free confidential emotional support, crisis intervention etc.

\section{Online chat \& text}

- Individuals can connect with a highly trained and empathetic professional without having to talk on the phone

- Text 741741 between 2pm-2am

Website: https://www.torontodistresscentre.com/

\section{Sherbourne Health Centre}

\section{Location \& contact information}

333 Sherbourne Street Toronto, Ontario M5A 2S5

Contact 416-324-4109 
- Free confidential counselling for LGBTQ2S+ folks, newcomers to Canada, homeless and underhoused peoples

- Sherbourne's Mental Health Team offers free-of-charge, confidential, walk-in, mental health counselling every Tuesday afternoon

Website: https://sherbourne.on.ca/mental-health-services/counselling-services/

\section{$\underline{\text { Spectra Helpine }}$}

Contact 905-459-7777 if you live in Brampton or Mississauga

Contact 1-877-298-5444 if you live in Caledon

- Serves individuals who live in Peel Region (Mississauga, Brampton, and Caledon)

- Provides free confidential distress and emotional support

- The helpline is open 24 hours of the day, 7 days of the week, and 365 days of the year

Website: https://www.spectrahelpline.org/our-services/our-services

\section{Family Services of Peel}

\section{Location \& Contact information}

151 City Centre Drive, suite 501, Mississauga ON, L5B 1M7

Contact 905-453-5775

- Free confidential walk in counselling every Wednesday from $12 \mathrm{pm}-8 \mathrm{pm}$

Website: https://fspeel.org/services/counselling/walk-in-counselling/ 


\section{Appendix H}

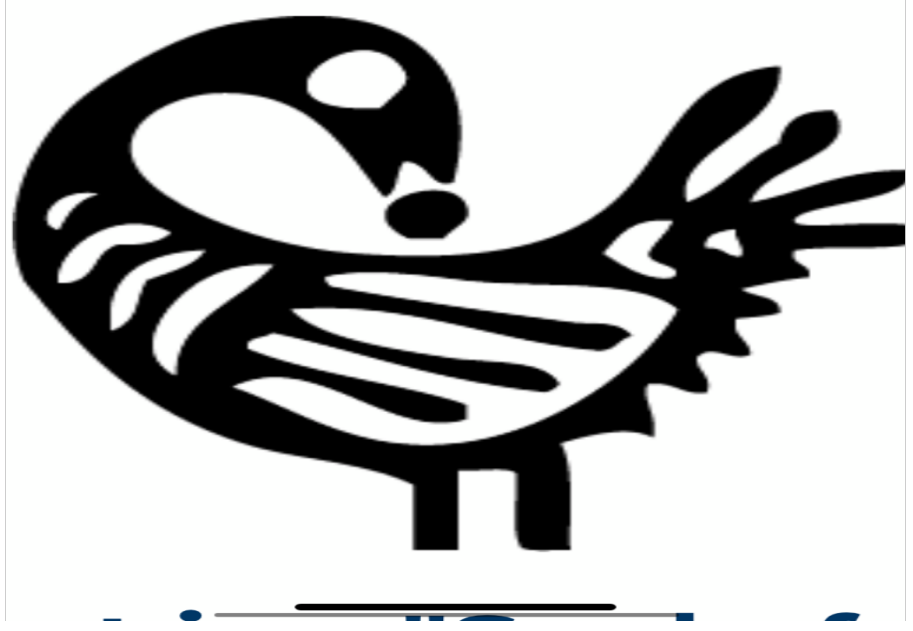

Looking backwards and learning how to move forward. 


\section{Appendix I}

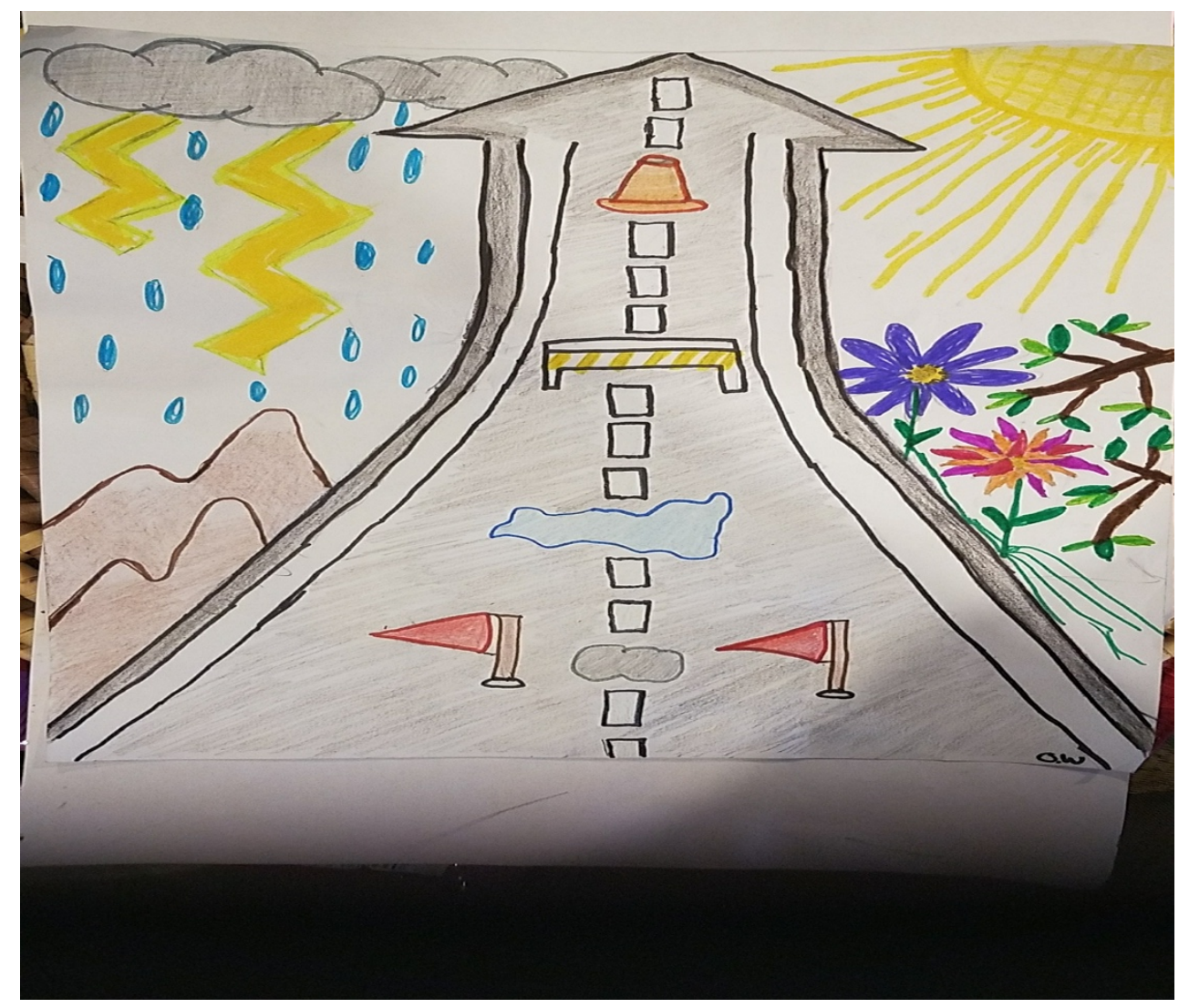

At first, I wanted to use a superwoman and doing a whole spin on it. So, superwoman but instead of $\mathrm{S}$ on our chest or $\mathrm{W}$ or like a wonder woman it would be like an $\mathrm{R}$ and $\mathrm{R}$ representing resilience. So, I was thinking of that at first but then I was like no I do not think that would be it or fit. So, I am just like really reflect what did telling your story mean to you. So, I kept googling and brainstorming and so I drew a road going upward or forward and this road really represents like when I told my story it made me realize that I came a long way when it came to my education. I came a long way but also, I still have a way to go. With that being said while the road is going upwards there was little obstacles in the way. So, the first obstacle was, it was supposed to be a rock that is gracing the red flag but that is like an obstacle I encountered throughout my educational experiences. There were red flags going up, things that were wrong and red flags going up but I was not really paying attention to the red flags, so I still proceeded ahead. Then the blue thing in the middle or object was supposed to be water or a pond. So, it was like I was getting to a slippery place. As I was moving up, I was slipping and sliding in terms of being focused and dedicated. As I move up there is a caution/hazard sign and it is just for me to proceed learning opportunities with caution and know what the intention behind it is. Going up is supposed to be that orange little thing at the top is supposed to be a pilon and meaning that pilons are not so big but they still hold value and they still give you a warning. Those are just significance of obstacles I kept on overcoming and as I got to each grade there was an obstacle that I had to overcome or a hurdle that I had to jump over. On the left side as you see its mountains, rainfall, thunder, and lightning and a grey cloud. It is just to indicate that some days while I was in school were very cloudy, there were storms I had to overcome and there were 
mountains I had to climb and reach to higher heights and reach my peak of success. So that is why I put the mountains there, so I am trying to reach and climb to my peak of success. On the right side its sunshine, it is flowers, its branches and leaves meaning there were good days despite my road to success, there was good days. with the flowers meaning in the midst of adversity I can still bloom and flourish. With the branches and the leaves, I can still branch off and grow despite what was in my way of trying to hinder my success. The sunshine meaning there are brighter days ahead and there is always going to be brighter days despite what is in your way to impede your success. So that is pretty much it, good days, bad days and as I am still on this road to education, I came a long way that is why the road is very long and goes towards a certain direction. I came a long way but there is still, I still have some ways to go when I am climbing up that educational ladder. 


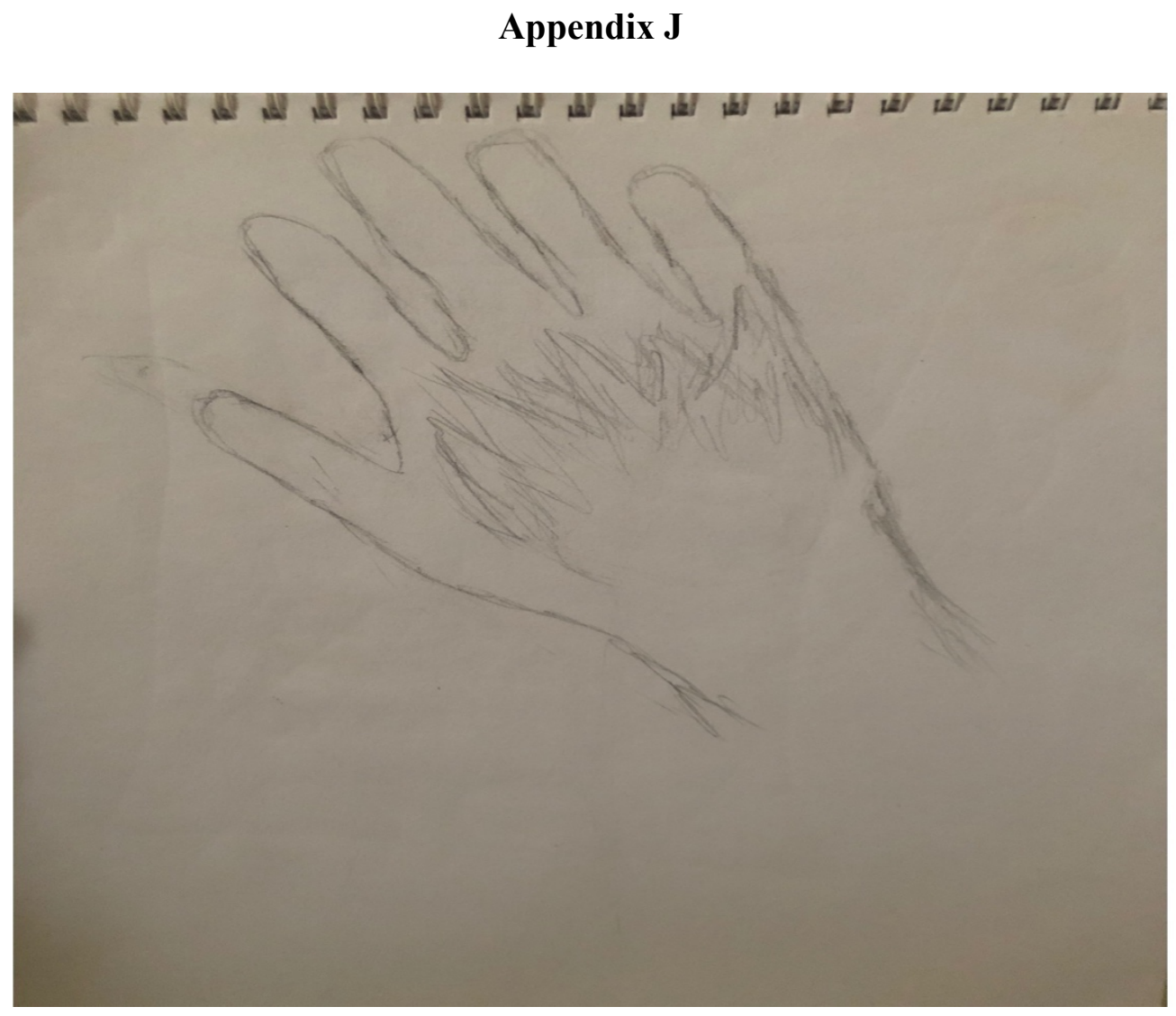

The image means being able to share my experiences to help highlight the academic system for black girls and the importance of having a voice and position to share these experiences. This image is connected to me telling my story through a lived experienced that has a success story at the end and wanting to support of black girls in being able to overcome challenges in the academic system so that they may also have success stories and experiences. 


\section{References}

Allen, Q., \& White-Smith, K. A. (2014). "Just as bad as Prisons": The challenge of dismantling the school-to-prison pipeline through teacher and community education. Equity \& Excellence in Education, 47(4), 445-460. doi:10.1080/10665684.2014.958961

Amoah, J. (2007). Building sandcastles in the snow: Meanings and misconceptions of the development of Black feminist theory in Canada. In N. Massaquoi \& N. Wane (Eds.), Theorizing Empowerment: Canadian Perspectives on Black Feminist Thought (pp. 94118). Toronto: Inanna Publications and Education Inc

Bailey, M. (2013). New Terms of Resistance: A Response to Zenzele Isoke. Souls: A Critical Journal of Black Politics, Culture, and Society, 341-343.

Baines, D. (2017). Anti-oppressive practice: Neoliberalism, inequality and change. In D. Baines, (Ed.) Doing anti-oppressive practice: Social justice social work, 3rd Edition (pp. 30-51). Halifax: Fernwood Press.

Blair, C. M. (2014). African American Women's Sexuality. A Journal of Women's Studies, 4-10.

Borland, K. (1991) 'That's Not What I Said: Interpretive Conflict in Oral Narrative Research', in S. Berger Gluck and D. Patai (eds) Women's Words: The Feminist Practiceof Oral History, pp. 63-76. New York: Routledge.

Briggs, A. Q. (2018). Second generation Caribbean black male youths discuss obstacles to educational and employment opportunities: A critical race counter-narrative analysis. Journal of Youth Studies, 21(4), 533-549. doi:10.1080/13676261.2017.1394997

Carr, P., \& Klassen, T.R. (1997). Different perceptions of race in education: Racial minority and White teachers. Canadian Journal of Education, 22(1), 67 
Carter, S.M. \& Little, M. (2007) Justifying knowledge, justifying method, taking action: Epistemologies, methodologies and methods in qualitative research, Qualitative Health Research, 17(10), 1316-1328.

Chambers, T. V. (2009). The "receivement gap": School tracking policies and the fallacy of the “achievement gap.” Journal of Negro Education 78, no. 4, 417-431.

Clarke, J, Pon, G. Benjamin, A. Bailey, A. (2015). Ethnicity, Race, Oppression, and Social Work: The Canadian Case. International Encyclopedia of the Social \& Behavioral Sciences, 2nd Edition, 152-156.

Codjoe, H. (2006). The role of an affirmed black cultural identity and heritage in the academic achievement of African-Canadian students. Intercultural Education, 17(1), 33-54

Connelly, M. F., \& Clandinin, J. D. (1990). Stories of experience and narrative inquiry. Educational Researcher, 19(5), 2-14. doi:10.2307/1176100

Crenshaw, K., Ocen, P., \& Nanda, J. (2015). Black Girls Matter: Pushed out, overpoliced, and underprotected. Retrieved from https://www.atlanticphilanthropies.org/wpcontent/uploads/2015/09/BlackGirlsMatter_Report.pdf

Creswell, J. W. (2013). Qualitative inquiry and research design (3rd ed.). Thousand Oaks, California: SAGE Publications.

Dei, G. J. S. (1997). Race and the production of identity in the schooling experiences of African Canadian youth. Discourse: Studies in the Cultural Politics of Education, 18(2), 241-257. doi:10.1080/0159630970180206

Dei, G. J. S. Mazzuca, J., McIsaac, E., \& Zine, J. (1997). Reconstructing 'drop out': A Critical ethnography of the dynamics of Black students' disengagement from school. Toronto: University of Toronto Press 
Dei, G. J. S. (2008). Schooling as community: Race, schooling, and the education of African Youth. Journal of Black Studies, 38(3): 346-366.

Duhaney, P. (2010). why is our educational system still guilty of whiteness? Canadian Social Work Review / Revue Canadienne De Service Social, 27(1), 95-111.

Dungee-Anderson, D., \& Cox, L. A. (2000). Conflicting Gender Role Perceptions Among Middle Class African American Males and Females. Race, Gender, \& Class, 99-120.

Fanon, F. (1967). Black skin, white mask. New York: Grove Press.

Fasula, A. M., Carry, M., \& Miller, K. (2014). A Multidimensional Framework for the Meanings of the Sexual Double Standards and its Application for the Sexual Health of Young Black Women in the U.S. The Journal of Sex Research, 170- 183.

Faulkner, S. S., \& Faulkner, C. A. (2016). Research methods for social workers: A practicebased approach (Second ed.) Oxford University Press.

Fraser, H. (2004). Doing narrative research: Analysing personal stories line by line. Qualitative Social Work, 3(2), 179-201. doi:10.1177/1473325004043383

Galabuzi, G. E. (2006). Canada's economic apartheid: The social exclusion of racialized groups in the new century. Toronto: Canadian Scholars' Press.

Galabuzi, G.E. (2014). Race and the Streaming of Ontario's Children and Youth in Restacking the Deck: Streaming by race, class and gender in Ontario Schools. Canadian Centre for Policy Alternatives.

Gibson, K., O’Donnell, S., Rideout, V., (2007). The project-funding regime: Complications for community organizations and their staff. Canadian Public Administrative Journal, 411436. 
Grace, J. E., Nelson, S. L., \& Nelson, S. L. (2019). "tryin' to survive": Black male students' understandings of the role of race and racism in the school-to-prison pipeline. Leadership and Policy in Schools, 18(4), 664-680. doi:10.1080/15700763.2018.1513154

Greenidge, W. L., \& Daire, A. P. (2010). The relationship between emotional openness and the attitudes towards seeking professional counseling of English-Speaking Caribbean college students. International Journal for the Advancement of Counselling, 32(3), 191-201. doi:10.1007/s10447-010-9100-6

Hill-Collins, P. (1999). Black feminist thought: Knowledge consciousness and the politics of empowerment. Boston: Unwin Hyman

Hills-Collins, P. (2000). Black Feminist Thought. New York and London: Routledge.

Hill-Collins, P., Blige, S. (2016). Intersectionality. Oxford: Polity Press

Henry, F., \& Tator, C. (2010). The colour of democracy: Racism in Canadian society (4th ed.). Toronto: Nelson Education.

Herising, F. (2005). Interrupting positions: Critical thresholds and queer pro/positions. In L. Brown \& S. Strega (Eds.), Research as Resistance (pp. 127-152). Toronto: Canadian Scholars' Press

Hooks, B. (2004). We Real Cool: Black Men and Masculinity. New York: Routledge.

Hope, E. C., Skoog, A. B., \& Jagers, R. J. (2015). It'll never be the white kids, it'll always be us: Black high school students' evolving critical analysis of racial discrimination and inequity in schools. Journal of Adolescent Research, 30(1), 83-112.

doi: $10.1177 / 0743558414550688$ 
James, C. E., Este, D., Bernard, W. T., Benjamin, A., Lloyd, B., \& Turner, T. (2010). Race and Well-being: The lives, hopes, and activism of African Canadians. Halifax, NS: Fernwood Publishing.

James, C.E. \& Turner, T. (2017). Towards Race Equity in Education: The Schooling of Black Students in the Greater Toronto Area. Toronto, Ontario, Canada: York University.

Johnson, M. S. (2013). Strength and Respectability: Black Women's Negotiation of Racialized Gender Ideals and the Role of Daughter--Father Relationships. Gender and Society, 889-912.

Kao, G., \& Thompson, J. S. (2003). Racial and ethnic stratification in educational achievement and attainment. Annual Review of Sociology, 29(1), 417-442. doi:10.1146/annurev.soc.29.010202.100019

Katshunga, J., Massaquoi, N., Wallace, J. (2020). Black Women in Canada. Retrieved from http://behindthenumbers.ca/shorthand/black-women-in-canada/

Kelly, S. (2009). The black-white gap in mathematics course taking. Sociology of Education, 82(1), 47-69. doi:10.1177/003804070908200103

Kleinman, S. and Copp, C. (1993) Emotions and Fieldwork. London: Sage.

Kumsa Kuwee, M; Mfoafo-M'Carthy, M; Oba, Funke; Gaasim, S (2014). The Contours of AntiBlack Racism: Engaging Anti-Oppression from Embodied Spaces. Journal of Critical Anti-Oppressive Social Inquiry. 1, pp. 21-38

Lawrence, B., \& Dua, E. (2005). Decolonizing anti-racism. Social Justice, 32(4), 120- 143.

Leseho, J. \& Block, L. (2005). “Listen and I tell you something'”: Storytelling and social action in the healing of the oppressed. British Journal of Guidance \& Counselling, 33 (2), 175197. 
Meiners, E. (2007). Right to be hostile: Schools, prisons, and the making of public enemies. New York: Routledge.

Moffatt, K. J. (2019). Arts-Based reflection. In Postmodern social work: Reflective practice and education (pp.173-190). Columbia University Press.

Morris, E. W. (2007). "Ladies" or "loudies"?: Perceptions and experiences of black girls in classrooms. Youth and Society, 38(4), 490-515.

Neeganagwedgin, E. (2014). Narratives from Within: Black Women and Schooling in the Canadian Context. Alberta Journal of Educational Research, 59(2), 226-246

Neuman, L.W. (2013). The meaning of methodology. In Social Research methods: Quantitative and qualitative approaches (7th ed) Boston: Pearson Education Inc

Nouvet, E., Sinding, C., Graham, C., Vengris, J., Fudge Schormans, A., Fullwood, A., \& Skeene, M. (2019). What are you (un)doing with that story? Qualitative Social Work, 18(3), 514529. doi:10.1177/1473325017735884

Oba, O. (2018). It takes a village-schooling out of place: schooling experiences of black African youth in Waterloo Region. (Theses and Dissertations Comprehensive).

OCSWSSW. (2020). About social workers. Retrieved from https://www.ocswssw.org/about-us/about-sw/

Olson, K. and Shopes, L. (1991) 'Crossing Boundaries, Building Bridges: Doing Oral History among Working-Class Women and Men', in S. Berger Gluck and D. Patai (eds) Women's Words: The Feminist Practice of Oral History, pp. 189-204. New York: Routledge.

Orenstein, P. (1994). Schoolgirls: Young women, self-esteem and the confidence gap. New York: Bantam Doubleday Dell Publishing Group Inc 
Owusu-Bempah, A. (2014). Black males' perceptions of and experiences with the police in Toronto

Padgett, D.K. (2017). Qualitative methods in social work research. (3rd ed). Los Angeles: SAGE

Pon, G., Gosine, K. \& Phillips, D. (2011). Immediate response: Addressing anti-Native and Anti-Black racism in child welfare. International Journal of Child, Youth and Family Studies, $3 \&$ 4, 385-409.

Prah, H. A. (2016). Viewing education in Canada through an intersectional auto-ethnographic lens. Social Alternatives, 35(3), 25-32

Rosenthal, G. (2003). The healing effects of storytelling: On the conditions of curative storytelling in the context of research and counseling. Qualitative Inquiry, 9(6), 915- 933.

Salole, A. T., \& Abdulle, Z. (2015). Quick to punish: An examination of the school to prison pipeline for marginalized youth. Canadian Review of Social Policy, (72-73), 124.

Schroeter, S., \& James, C. E. (2015). "we're here because we're black": The schooling experiences of French-speaking African Canadian students with refugee backgrounds. Race Ethnicity and Education, 18(1), 20-39. doi:10.1080/13613324.2014.885419

Solorzano, D. G., \& Yosso, T. J. (2002). Critical race methodology: Counter-storytelling as an analytical framework for education research. Qualitative Inquiry, 8(1), 23-44.

doi: $10.1177 / 107780040200800103$

Tyson, K., Darity, W., \& Castellino, D. R. (2005). It's not "A black thing": Understanding the burden of acting white and other dilemmas of high achievement. American Sociological Review, 70(4), 582-605. doi:10.1177/000312240507000403

Walby, S. (1989). theorising patriarchy. Sociology, 23(2), 213-234. 
doi:10.1177/0038038589023002004

Wane, N. (2007). African women a Canadian history: Demanding our place in the curriculum. In N. Massaquoi \& N. Wane (Eds.), Theorizing empowerment Canadian perspectives on Black feminist thought (pp. 129-154). Toronto: Inanna Publications and Education Inc.

Watson, L. B., Robinson, D., Dispenza, F., \& Nazari, N. (2012). African American Women's Sexual Objectification Experiences: A Qualitative Study. Psychology of Women Quarterly, 458-475.

Webber, M. E. (2017). "We don't love these hoes" exploring misogynoir and black male patriarchy through sexual double standards (Order No. 10280811). Available from ProQuest Dissertations \& Theses A\&I; ProQuest Dissertations \& Theses Global. (1900208337). Retrieved from http://ezproxy.lib.ryerson.ca/login?url=https://searchproquest-com.ezproxy.lib.ryerson.ca/docview/1900208337?accountid=13631

Williams, C. C. (2019). Critical oral history: Reflections on method and medium. Qualitative Social Work, 18(5), 787-799. doi:10.1177/1473325018777902

Wood, M. (2011). Banking on education: Black, Canadian females and schooling. Retrieved from: http://amicus.collectionscanada.gc.ca/thesescanadabin/Main/BasicSearch?coll=18\&l=0\&v=1 [Proquest dissertation and Theses full text] Yang, J. L., Anyon, Y., Pauline, M., Wiley, K. E., Cash, D., Downing, B. J., . . Pisciotta, L. (2018). "we have to educate every single student, not just the ones that look like us": Support service providers' beliefs about the root causes of the school-to-prison pipeline for youth of color. Equity \& Excellence in Education, 51(3-4), 316-331. doi:10.1080/10665684.2018.1539358 